\title{
Article \\ A Spatiotemporal Statistical Method of Ship Domain in the Inland Waters Driven by Trajectory Data
}

\author{
Fan Zhang ${ }^{1}$, Xin Peng ${ }^{1, *} \mathbb{0}$, Liang Huang ${ }^{2,3}$, Man Zhu ${ }^{2,3}$, Yuanqiao Wen ${ }^{2,3}$ and Haitao Zheng ${ }^{1}$ \\ 1 School of Navigation, Wuhan University of Technology, Wuhan 430063, China; \\ michael_sf@whut.edu.cn (F.Z.); zht1992618@foxmail.com (H.Z.) \\ 2 National Engineering Research Center for Water Transport Safety, Wuhan 430063, China; \\ plaquemine@whu.edu.cn (L.H.); man.zhu.393@whut.edu.cn (M.Z.); yqwen@whut.edu.cn (Y.W.) \\ 3 Intelligent Transportation Systems Research Center, Wuhan University of Technology, Wuhan 430063, China \\ * Correspondence: xinpeng@whut.edu.cn
}

check for updates

Citation: Zhang, F.; Peng, X.; Huang, L.; Zhu, M.; Wen, Y.; Zheng, H. A Spatiotemporal Statistical Method of Ship Domain in the Inland Waters Driven by Trajectory Data. J. Mar. Sci. Eng. 2021, 9, 410. https://doi.org/ $10.3390 /$ jmse 9040410

Academic Editor: Gabriele Bruzzone

Received: 18 February 2021

Accepted: 6 April 2021

Published: 12 April 2021

Publisher's Note: MDPI stays neutral with regard to jurisdictional claims in published maps and institutional affiliations.

Copyright: (c) 2021 by the authors. Licensee MDPI, Basel, Switzerland. This article is an open access article distributed under the terms and conditions of the Creative Commons Attribution (CC BY) license (https:// creativecommons.org/licenses/by/ $4.0 /)$.

\begin{abstract}
In this study, a method for dynamically establishing ship domain in inland waters is proposed to help make decisions about ship collision avoidance. The surrounding waters of the target ship are divided to grids and then calculating the grid densities of ships in each moment to determine the shape and size of ship domain of different types of ships. At last, based on the spatiotemporal statistical method, the characteristics of ship domains of different types of ship in different navigational environments were analyzed. The proposed method is applied to establish ship domains of different types of ship in Wuhan section of the Yangtze River in January, February, July, and August in 2014. The results show that the size of ship domain increases as the ship size increases in each month. The domain size is significantly influenced by the water level, and the ship domain size in dry seasons is larger than in the wet seasons of inland waters.
\end{abstract}

Keywords: spatiotemporal statistical analysis; ship domain; AIS data; grid density; navigational environment

\section{Introduction}

With the vigorous development of the shipping industry in the inland waters of China, the navigational risk of ships has increased obviously. In order to decrease the collision of ships, in this work, a statistical analysis method of ship domain is proposed to organize the navigational ships scientifically. The concept of ship domain was proposed to define the safe navigation area around the navigating ships [1]. The ship domain method was widely applied to explore the ship collision avoidance, assess the navigational risk of ships, and estimate the waterway capacity [2-6]. There are some impact factors that should be considered when developing the ship domain model, including human factors, ship attributes, and navigation environment. The larger the area of ship domain, the safer the navigational environment for ships. The volume of the traffic flow is one important impact factor for determining the range of the ship domain. Therefore, some researchers explored the relationships between the ship domain size and ship attributes and then developed different kinds of ship domain model to satisfy different application scenes, i.e., the elliptical ship domain model [7,8], the unequal sector model [1], and the circular ship domain model $[9,10]$.

The marine radar provides the dynamic activity data of ships, including the velocity, heading, and position of ships. The marine radar data were utilized to statistically analyze the navigational regulations and establish ship domains in previous studies [9,11]. The amount of radar data is small, and it is difficult to present the total activity conditions of the regional ships. Automatic identification system (AIS) is required to be installed on passenger ships and other types of ships with a gross tonnage of over 300 tons, and the transmission interval time is from $1 \mathrm{~s}$ to $3 \mathrm{~min}$, including the detailed dynamic activity information of ships. AIS data were utilized to analyze the collision risk index between 
ships, the azimuth angle between ships, and the distance between ships and ship attributes to establish ship domains with different shapes and different areas [12,13].

AIS equipment is widely used in inland ships, and AIS data of inland ships can be utilized to research the ship domain in inland waters. Ships sailing on inland waters are susceptible to be influenced on the navigational environment. The navigation rules between inland waters and open waters have obvious differences. In previous studies, the ship domain construction methods of open waters were utilized to establish inland ship domains in inland waters according to the analysis of the relationships between ship domain size, ship length, and ship speed [14-16]. The navigation rules, meteorological conditions, and hydrologic conditions are the important influence factors of navigating ships in inland waters; therefore, those factors should be considered to establish inland ship domain. With the time and the navigation position change, the navigational environments and the characteristics of the ship traffic flow are constantly changing in the inland waters. In the traditional inland ship domain models, the dynamic characteristics of ship traffic flow were not considered in the traditional ship domain models. The navigational environment of ships in inland waters varies with the season and year. The navigational seasons of the inland waters are divided into the wet period (i.e., June, July, and August) and the dry period season (i.e., January, February, November, and December) based on the water flow in China. The activity characteristics of inland ships are obviously influenced by the navigational environments.

In this work, the navigational environments of inland waters, the attributes of inland ships, and the navigating characteristics of inland ships are considered to propose a spatiotemporal statistical method of establishing the inland ship domain. Based on the dynamic activity data of ships, the Yangtze River is a typical inland water, the Wuhan section is located in the middle stretch of the Yangtze, and there also are some law regulations to manage the ship traffic in Yangtze River (Changjiang Maritime safety administration, 2019, available online: https:/ / j.msa.gov.cn/xxgk/xxgkml/tzgg/hxtg/201911/t2019112 8_633092.shtml (accessed on 9 April 2021)). The proposed method was utilized to establish ship domains of different types of ships here in 2014 and to analyze the characteristics of ship domains of inland waters. This work is beneficial for making ship collision avoidance decisions for deck officers.

The rest of the paper is organized as follows: Section 2 gives a literature review of ship domain models. Section 3 presents a spatiotemporal statistical analysis method of inland ship domain based on AIS data. In Section 4, the proposed model is used to analyze the characteristics of ship domain in different months as well as to explore relationships between ship domain size and ship size in Wuhan section of the Yangtze River. Discussion is presented in Section 5, and the conclusion is summarized in Section 6.

\section{Literature Review}

The ship domain model is widely used in the opening waters. At first, the ellipse ship domain model was proposed to analyze the impacts of the International Regulations for Preventing Collisions at Sea, and this model was utilized in various scenarios [1]. The ship is not located in the center of the determined safety area based on the oval ship domain model [17]. The circular ship domain model was proposed to improve the previous models, and it can smooth the boundaries of ship domain [9].

Coldwell [11] proposed a ship domain model for a ship under the overtaking statue according to analyze the ship activity data. Then, a more sophisticated ship domain model was proposed, which is suitable for the enclosed water considering the ship operating factors and ship velocity $[18,19]$. However, it ignored the human factors and the navigational environment factors. With the development of the intelligence algorithm, new breakthroughs have also been made in the research of ship domain. Pietrzykowski [20] applied the artificial neural network technology to train and obtain a dynamic fuzzy ship domain model, which incorporated human experience and ship characteristics but no navigational environmental factors. Wang [21] proposed a fuzzy four-elements ship do- 
main model to evaluate collision risk degree of ship space based on fuzzy set theory. The evaluation results have shown advantages. The artificial neural network was utilized to investigate relationships between ship domain and its influencing factors [22,23]. The obtained results have better fitting degree compared to traditional methods.

There were some studies focused on exploring the relationships between ship domain size and ship attributes in the inland waters. Jia [24] proposed a variable scale ship domain model to study the relationships between ship domain size in restricted waters and ship attributes (i.e., ship size and ship speed). For the narrow channels, Liao [25] constructed a ballistic-shape ship domain model to consider the ship maneuverability and navigational conditions. $\mathrm{Xu}$ [26] went further to analyze relationships of ship domain size and ship size, movement performance, and water area, as well as mutual position of other ships, and put forward a three-dimensional ship domain model for avoiding collision of inland vessels in China. Chen [27] analyzed effects of ship maneuverability and hydrodynamics and proposed a rectangular ship domain model for the bridge water. It was found that ship domain size is related to bridge pier width, ship breadth, and one-way navigation. Moreover, the impacts of water flow conditions on ship navigation have also been taken into consideration for establishing ship domain model [28].

Recently, AIS technology provides a new way to explore ship behaviors, analyze water traffic characteristics, and detect ship conflicts [29-34]. Modeling ship domain based on AIS data has become a hot research point. Andrew [28] applied a domain analysis approach to access the risk of collision between vessels and related to port capacity. Moreover, this paper pointed out that some factors should be concerned in the processes of establishing and analyzing the ship domain, including the data availability, data quality, the local geography, and the local perceptions in the study area. Zhang [35] studies probability distribution of ship safety distance and conducted statistical experiments on the safety distances of ships of different types and sizes based on AIS data in harbor area of Singapore. It is concluded that the most suitable probability distribution of safety distance is the logarithmic positive state and gamma distribution. The study of ship domain in maritime applications is very significant for the safety of traffic in waters, which promotes the other research, i.e., maritime anomaly detection, collision prediction, and path planning [36]. Pietrzykowski et al. [37,38] analyzed characteristics of ship domain in the waters of traffic separate scheme based on AIS data and identified ship domain parameters based on various field decision criteria in the southern Baltic. To explore differences of ship domain in different application waters, the ship domain models based on AIS data were applied in three kinds of waters, which are open water at sea, restricted water, and poor visibility water, respectively $[31,39,40]$. The experimental results showed that the navigational environment is a great influence factor on the ship domain model. In addition, maneuverable water is another factor affecting the shape and size of ship domain in open and restricted waters in open and restricted waters based on AIS data [41-43]. In a word, ship domain is widely used in ship collision risk assessment $[2,44,45]$, ship collision avoidance analysis [46], and near miss detection [32,47].

There are three methods to build ship domain model, including statistical analysis methods, analytic expression method, and intelligent algorithm according to the previous researchers. For statistical methods, data sources used in these methods vary from early radar observation data to recent AIS data, recording abundant information used to explore more realistic characteristics of ship domain. Analytic methods take ship maneuverability into consider in the construction of ship domain model but ignore effects of navigator and environmental factors. Various intelligent algorithms were utilized to quantize the ship domain in different application scenarios, and there were some impact factors that were ignored, i.e., human and navigational environment. At present, almost all research focused on the static ship domain, the dynamic navigational conditions, and environments should be considered to establish the dynamic ship domain. 


\section{Statistical Analysis Method of Ship Domain}

The ship domain is defined as an area that the navigator should maintain safe distance between other vessels [7]. In this study, all navigational trajectories of the ship object in the research area are utilized to dynamic statistic the grid density of the nearest other ships, and then establish ship domain. The necessary foundation data of ship domain model can be obtained from the AIS data, including the speed of ships, the heading of ships, and the position of ships. The statistical analysis method of ship domain includes four parts, which are shown in Figure 1.

- Data preprocessing. It is necessary to preprocess the foundation data of ships before establishing and statistical analyzing the ship domain, including data cleaning, data interpolation, and classification.

- Establish the grid density map of individual ship. The research area is divided into the same size grids; the initial value of each grid is 0 . It is necessary to dynamically search for the closest ship between and the target ship at $1 \mathrm{~s}$ interval time. At one time, the value of each located grids of the closest ship is denoted as 1 . Accumulating the values of the same grid number at each moment, the grid density map of individual ship can be established. As the heading and position of the target ship changes with time, the relative orientation of other ships should be dynamic.

- Grid density map aggregation. In order to analyze the regional characteristics of ship domain of different types of ship, each grid density map of all individual ships of the same type were integrated.

- Analyze different types of ship domain. Establishing the ship domain is influenced by some factors. In this work, the ship size and the navigational environments are considered to statistically analyze different ship domains in inland waters. In addition, the classification regulations of the two impact factors of ship domain are proposed.

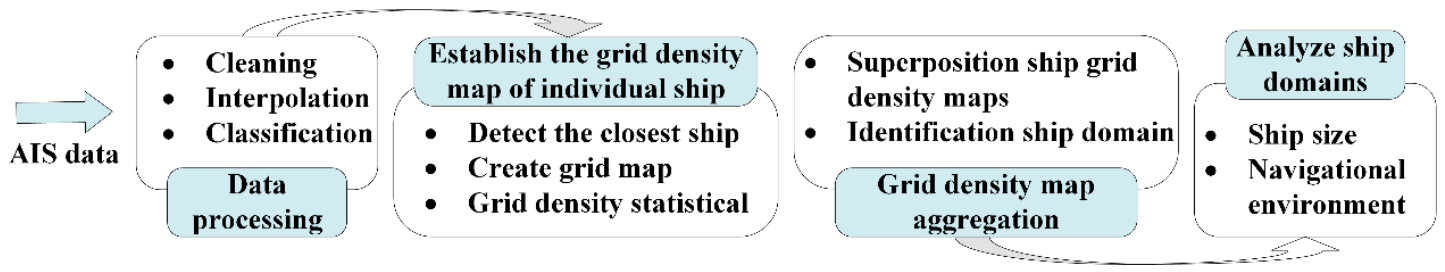

Figure 1. The modeling process of the statistical analysis model of ship domain based on automatic identification system (AIS) data.

\subsection{AIS Data Processing}

AIS data provide the activity information of ships, including the position, heading, and velocity of ships. The noise AIS data should be cleared before being utilized to establish the ship domain. The noise data include the following: the position of ship is not in the water areas; the velocity is smaller than $0.1 \mathrm{knot}$; and the heading is not in the scope of 0 to $360^{\circ}$. The static information of ships can be obtained from public websites (i.e., www.shipfinder.com (accessed on 9 April 2021), and it can also be provided by Lloyd's dataset. The static information includes the ship length, width, tonnage, and the draft. Ships within the research areas are divided into three groups based on their length. The time interval of the original AIS data is from $1 \mathrm{~s}$ to $3 \mathrm{~min}$. The original AIS data should be interpolated to the same interval data. The interpolation method [48] is utilized to adjust the original AIS data with a regular interval, $1 \mathrm{~s}$. Based on the preprocessed AIS data, the ship domain of ships in the same group can be analyzed respectively.

\subsection{Calculating the Grid Density of Individual Ship}

After determining a rectangle research water around the target ship, the horizontal direction is the heading direction of the target ship. The initial value of each grids is 0 . Based on the requirements of the statistical accuracy of ship domain, the research water is 
divided into the same size grids. The distances between the target ship and the other ships are calculated, and then the nearest ship to the target ship is found. The AIS equipment is installed on ship to provide the dynamic position of ship, which is the antenna position of AIS equipment. In this study, the shape of ships is regarded as a rectangle, and the antenna of AIS equipment is considered to be installed on the center of ship. Based on the ship's position obtained from AIS data, ship width, and ship length, the location range of ship can be calculated. The information of ship width and ship length are obtained from the Maritime Safety Administration (MSA) and also obtained from public websites (marinetraffic.com, maritime.ihs.com). The value of the located grids of the nearest ship should be denoted as 1 . Therefore, the grid density of the target ship at some point can be calculated, as shown in Figure 2.

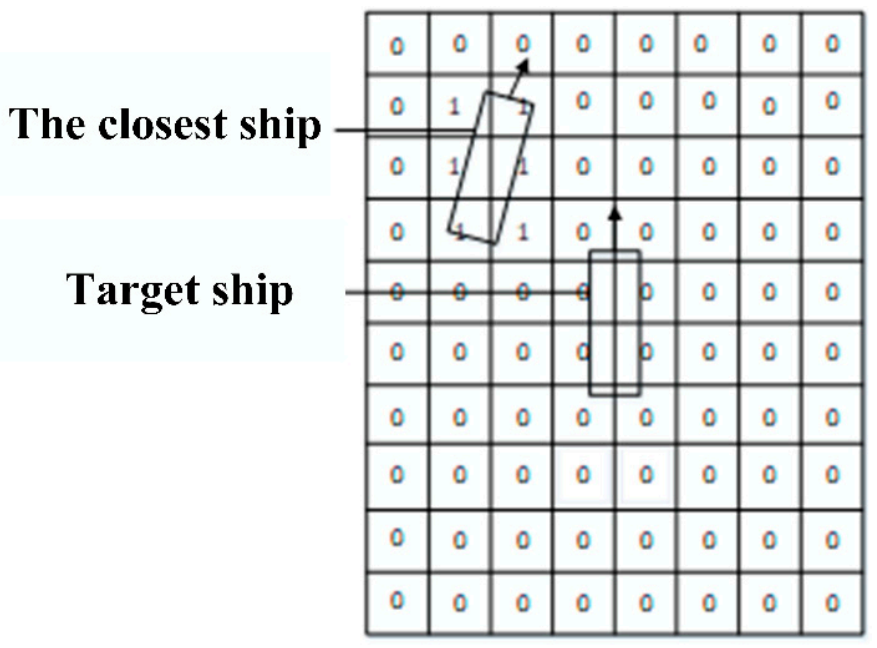

Figure 2. The grid density diagram of individual target ship at one point.

The grid density of the target ship during the whole voyage can be calculated according to the accumulated values of the same grid number at each moment, as shown in Figure 3. The position and the heading of the target ship is constantly changing. The relative direction between the target ship and the nearest ship changes over time. In order to ensure the heading directions of the target ship are parallel to the $y$-axis of the grid diagram, it is necessary to convert the angle between the target ship and the nearest ship at each moment [39]. The angle conversion diagram is shown in Figure 4. In Figure $4, \alpha$ is the angle between the heading of the nearest ship and heading of the target ship, $360-\beta$ is the angle between the heading of the target ship and the north direction, and $\gamma$ is the angle between the heading of the nearest ship and the north direction. 


\begin{tabular}{|l|l|l|l|l|l|l|l|}
\hline 0 & 0 & 0 & 0 & 0 & 0 & 0 & 0 \\
\hline 0 & 1 & 1 & 0 & 0 & 0 & 0 & 0 \\
\hline 0 & 1 & 0 & 0 & 0 & 0 & 0 & 0 \\
\hline 0 & 4 & 1 & 0 & 0 & 0 & 0 & 0 \\
\hline 0 & 0 & 0 & 0 & 0 & 0 & 0 & 0 \\
\hline 0 & 0 & 0 & 0 & 0 & 0 & 0 & 0 \\
\hline 0 & 0 & 0 & 0 & 0 & 0 & 0 & 0 \\
\hline 0 & 0 & 0 & 0 & 0 & 0 & 0 & 0 \\
\hline 0 & 0 & 0 & 0 & 0 & 0 & 0 & 0 \\
\hline 0 & 0 & 0 & 0 & 0 & 0 & 0 & 0 \\
\hline
\end{tabular}

Time 1

\begin{tabular}{|l|l|l|l|l|l|l|l|}
\hline 0 & 0 & 0 & 0 & 0 & 0 & 0 & 0 \\
\hline 0 & 0 & 0 & 0 & 0 & 0 & 0 & 0 \\
\hline 0 & 0 & 0 & 0 & 0 & 0 & 0 & 0 \\
\hline 0 & 0 & 0 & 0 & 0 & 0 & 0 & 0 \\
\hline 0 & 0 & 0 & 0 & 0 & 0 & 0 & 0 \\
\hline 0 & 0 & 0 & 0 & 0 & 1 & 1 & 0 \\
\hline 0 & 0 & 0 & 0 & 0 & 1 & 1 & 0 \\
\hline 0 & 0 & 0 & 0 & 0 & 0 & 1 & 1 \\
\hline 0 & 0 & 0 & 0 & 0 & 0 & 0 & 0 \\
\hline 0 & 0 & 0 & 0 & 0 & 0 & 0 & 0 \\
\hline
\end{tabular}

Time k-1

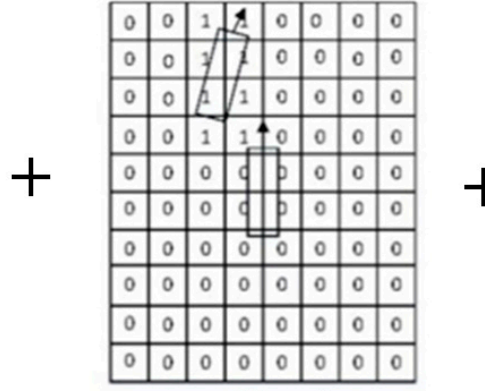

Time 2

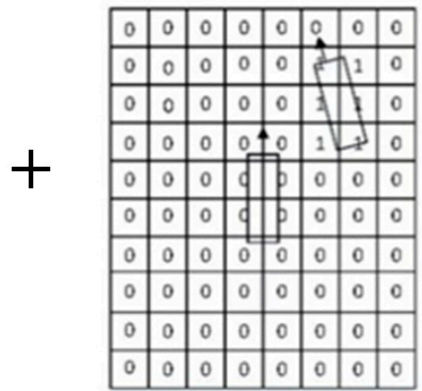

Time k

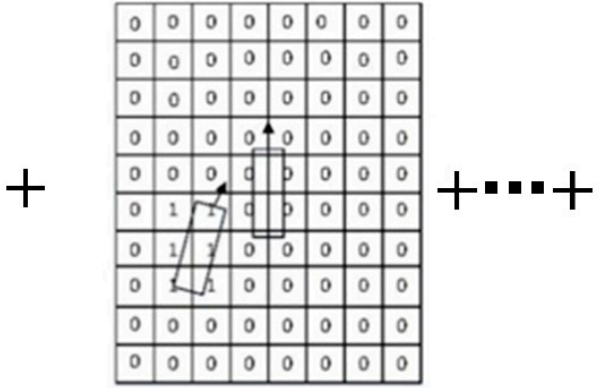

Time 3

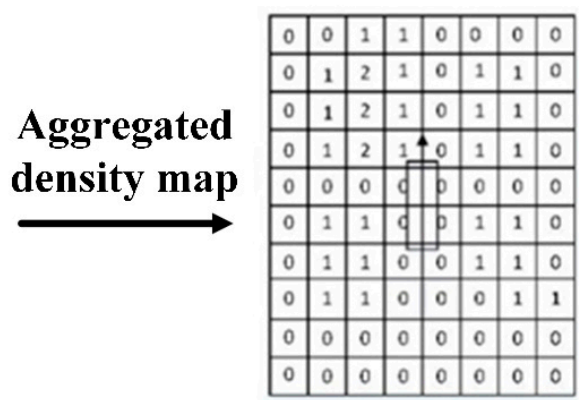

Figure 3. The grid density diagram of individual ship.

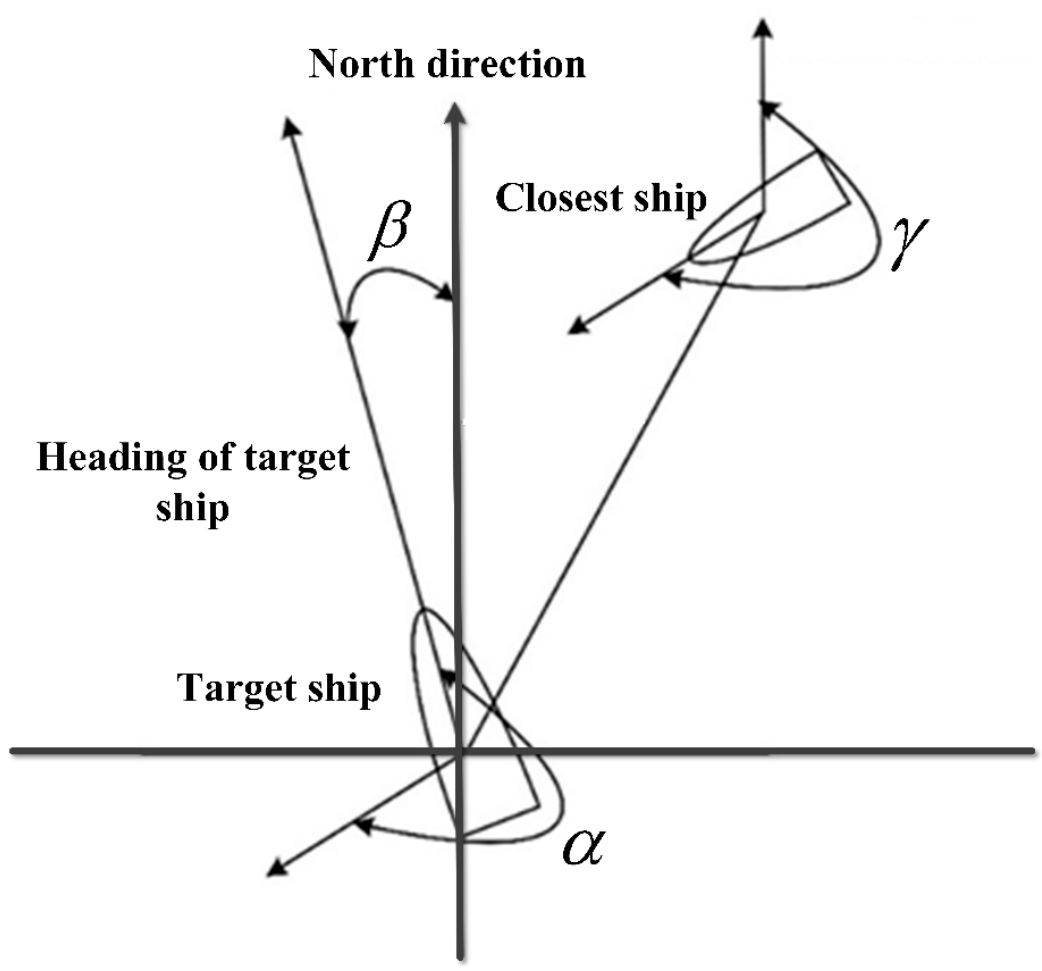

Figure 4. The angle conversion diagram.

\subsection{Establish the Ship Domain of Different Types of Ship}

Ships are divided into three categories based on the ship length, 60-79 m, 80-99 m, 100-120 m. The grid density maps of the same type of the individual ship are aggregated to calculate the ship domain of the same length range, and the aggregation processes is shown in Figure 5. The density value is normalized between 0 and 1 , and the grid is recovered with different color according to the density value. Then, the grid density map can be obtained, which can clearly show the shape for various types of ship domain. The size of 
the ship domain can be calculated by segmenting the grid density map [31,40], as shown in Figure 6 . The number of grids between the intersect points formatted by the cutting line and the density curve denotes the length of the ship domain.

\begin{tabular}{|l|l|l|l|l|l|l|l|}
\hline 0 & 0 & 0 & 0 & 0 & 0 & 0 & 0 \\
\hline 0 & 1 & 1 & 0 & 0 & 0 & 0 & 0 \\
\hline 0 & 1 & 1 & 0 & 0 & 0 & 0 & 0 \\
\hline 0 & 1 & 1 & 0 & 0 & 0 & 0 & 0 \\
\hline 0 & 0 & 0 & 0 & 0 & 0 & 0 & 0 \\
\hline 0 & 1 & 1 & 0 & 0 & 0 & 0 & 0 \\
\hline 0 & 1 & 1 & 0 & 0 & 0 & 0 & 0 \\
\hline 0 & 1 & 1 & 0 & 0 & 0 & 0 & 0 \\
\hline 0 & 0 & 0 & 0 & 0 & 0 & 0 & 0 \\
\hline 0 & 0 & 0 & 0 & 0 & 0 & 0 & 0 \\
\hline
\end{tabular}

Ship 1

\begin{tabular}{|l|l|l|l|l|l|l|l|}
\hline 0 & 0 & 0 & 0 & 0 & 0 & 0 & 0 \\
\hline 0 & 0 & 0 & 0 & 0 & 0 & 1 & 0 \\
\hline 0 & 0 & 0 & 0 & 0 & 0 & 1 & 0 \\
\hline 0 & 0 & 0 & 0 & 0 & 2 & 1 & 0 \\
\hline 0 & 0 & 0 & 0 & 0 & 1 & 1 & 0 \\
\hline 0 & 0 & 0 & 0 & 0 & 0 & 1 & 0 \\
\hline 0 & 0 & 1 & 0 & 0 & 0 & 0 & 0 \\
\hline 0 & 2 & 1 & 0 & 0 & 0 & 0 & 0 \\
\hline 0 & 2 & 2 & 0 & 0 & 0 & 0 & 0 \\
\hline 0 & 0 & 2 & 0 & 0 & 0 & 0 & 0 \\
\hline
\end{tabular}

Ship n-1

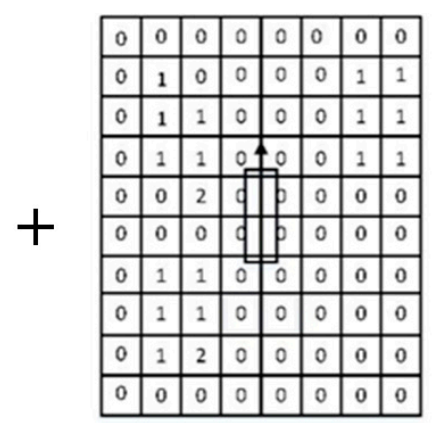

Ship 2

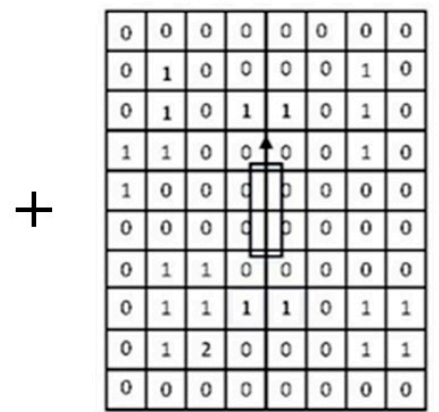

Ship n

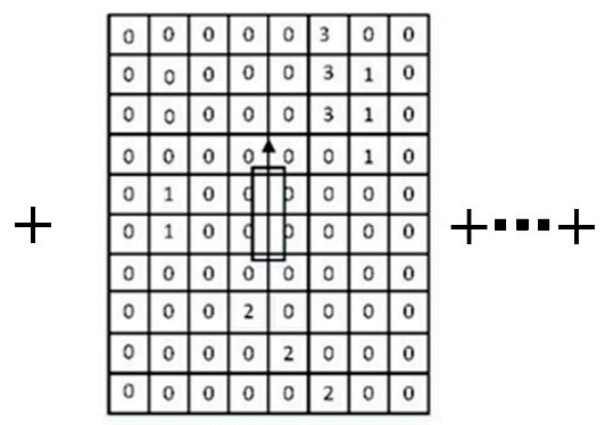

Ship 3

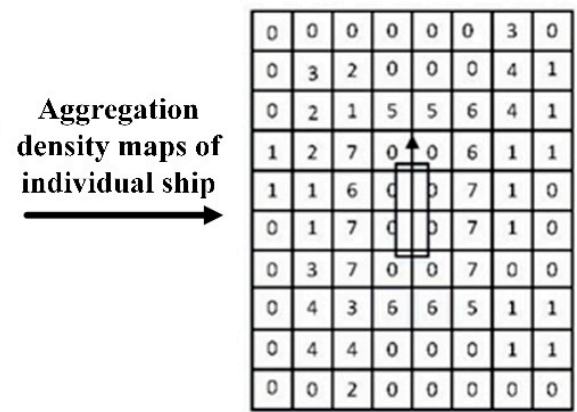

Figure 5. Grid density map of ships within a specific length range.

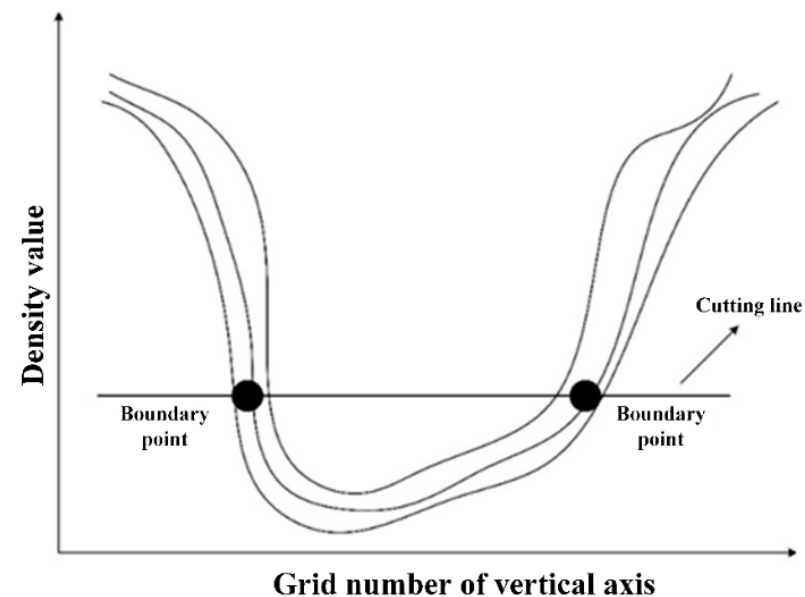

Figure 6. Domain section of ships in specific length range.

Characteristics of ship domain under different months and different navigational environment were compared. In inland waters, the ship can be divided into upbound ships and downbound ships based on the relationship between the navigating direction of ship and the flow direction, and the maneuvering modes of the two types of ship are different. The upbound ship is the ship going against the direction of water flow, and the downbound ship is the ship going along the direction of water flow Therefore, the AIS data are classified into downbound ships and upbound ships to analyze the characteristics of ship domain under different months and different navigational environments. 


\section{Experiments}

\subsection{Foundation Data and Research Area}

The Yangtze River is the "golden canal" of China. In this section, the proposed spatiotemporal statistical analysis method is used to establish and analyze the ship domains in a typical inland water, the Wuhan section of the Yangtze River. Figure 7 shows the study area from 30.533 to $30.706^{\circ} \mathrm{N}$ and from 114.296 to $114.508^{\circ} \mathrm{E}$. The length of the study water is about $30 \mathrm{~km}$, and the width is between 1 and $2 \mathrm{~km}$. When sailing a ship through the bridge areas, the maneuvering behavior of a sailing ship should be changed based on the ship traffic separation regulations. The bridge is regarded as an important environment factor of ship domain in the experiments. The red areas of Figure 7 are the bridge areas, including the Wuhan Baisha Chau Bridge, Wuhan Yangtze River Bridge, the Second Wuhan Yangtze River Bridge, and the Erqi Yangtze River Bridge.

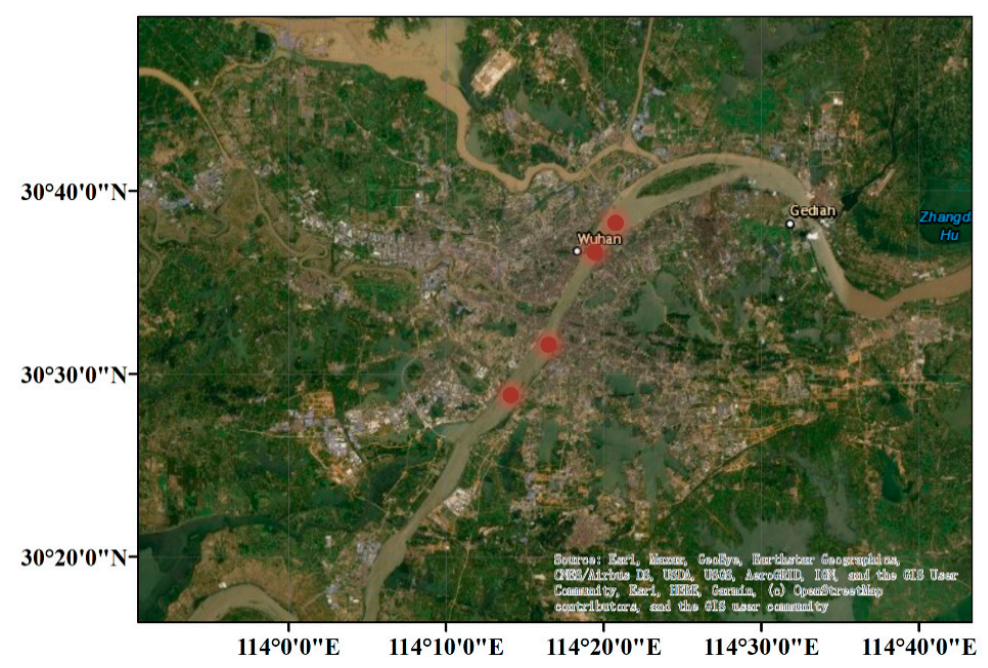

Figure 7. Study areas.

The Changjiang Maritime Safety Administration provided the AIS data and the static data of ships in the study area. There were 200 million records of AIS data of the study water in 2014. According to statistical analysis of the length of ships in each month of 2014, most of the ship lengths were in the range of 60-120 m, as shown in Figure 8. The ships were divided into three groups based on the ship length: 60-79, 80-99, and 100-120 m, respectively. The number of ships sailing on the study water and the traffic volume of the study water in each month were counted, and the statistical results were presented in Figure 9. We can see that the numbers of ships in February, March, and October were obviously less than the numbers of ships in other months in 2014.

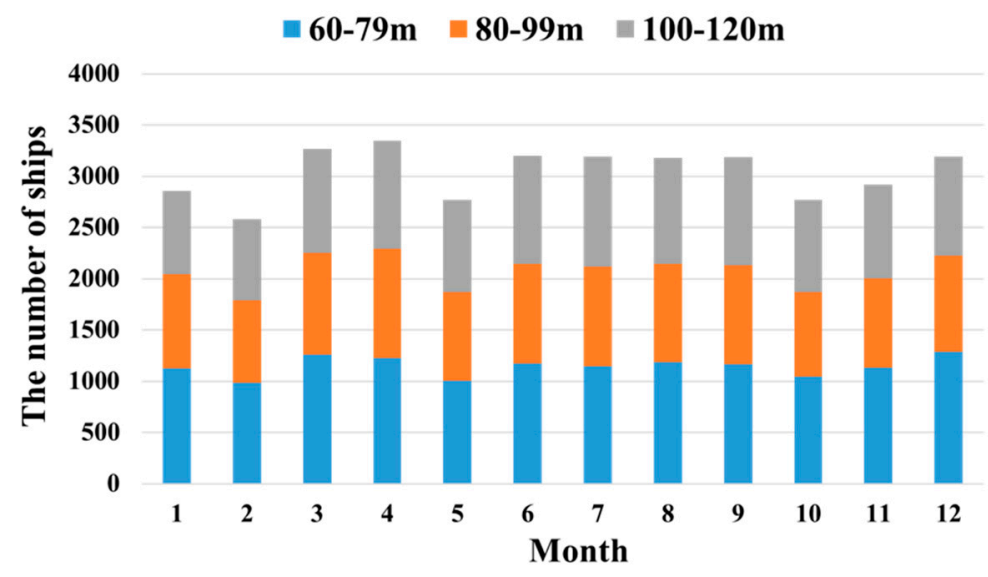

Figure 8. The number of ships within different ship length ranges. 


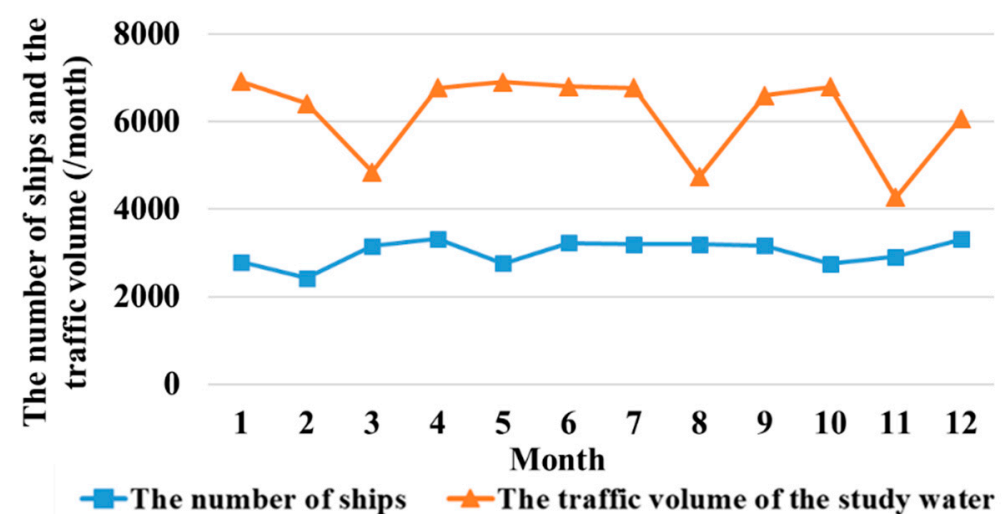

Figure 9. The number of ships and the traffic volume of the study water in 2014.

The water level is an important factor of ship maneuvering behavior. There are significant differences between ship domains in different water levels. The Wuhan Maritime Safety Administration provided the water levels in each month in 2014, and the comparison diagram of which is shown in Figure 10. In February, the Yangtze River was in the dry period, and the water level was lowest. In July, the Yangtze River was in the wet period, and the water level was highest. Therefore, the ship domains in the wet period and in the dry period were selected as samples to be statistically analyzed respectively in the experiments.

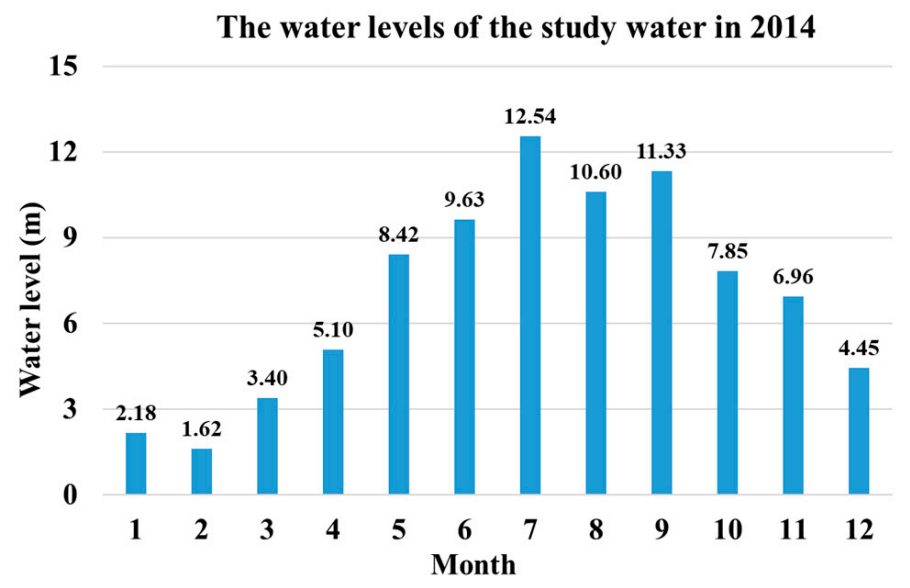

Figure 10. The water levels of the study water in 2014.

\subsection{Statistical Analysis of Ship Domain \\ 4.2.1. Establishing Ship Domains}

The study area was divided in each grid: there were 50 grids in $x$-axis direction, and there were 150 grids in $y$-axis direction. The establishment method of ship domains has been proposed in Section 3, which was utilized to establish the ship domains of different types of ship in each month in 2014. The water level is considered to be an important environment factor for establishing ship domains. Figure 10 shows that there were significant differences of the water levels between each month in 2014. January and February are dry seasons in the Yangtze River, and July and August were wet seasons. The four typical months of water level were selected as the sample months in this section, and ship domains of the four months were established. The ship domains of different length ships in January are shown in Figure 11. In Figure 11, the $x$-axis and $y$-axis present the number of grids in the horizontal direction and the vertical direction, respectively. The target ship is located in the center of figure, which is the intersection of two blue lines. Figure 11a-c is the ship domain of ship length in the range of 60-79, 80-99, and 100-120 m, respectively. The ship domains 
of different types of ship in other three months (February, July and August) are shown in the Appendix A.

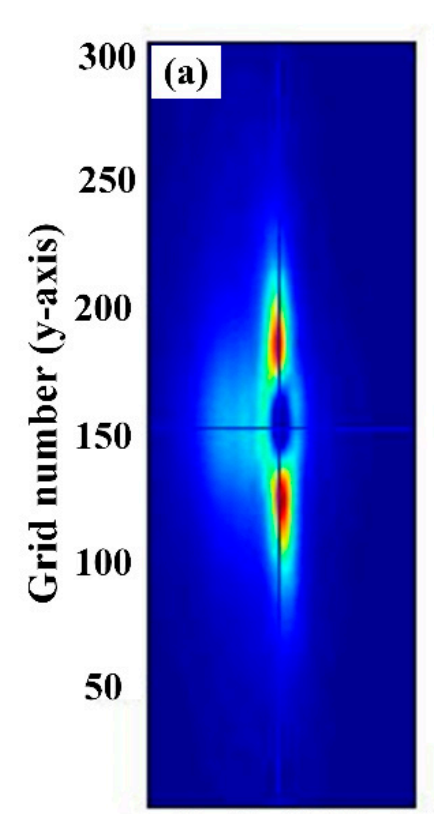

20406080100

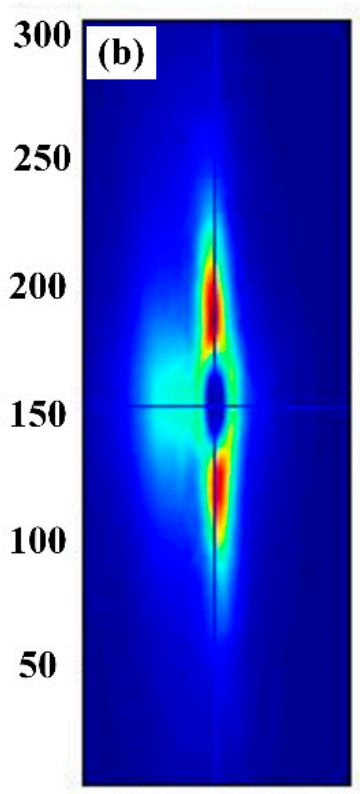

20406080100 Grid number (x-axis)

Figure 11. The ship domain of different types of ship in January 2014. (a-c) represent the ship domain of ships with 60-79 $\mathrm{m}$ length, 80-99 m length, and 100-120 m, respectively.

The ship domain maps show that the shape of ship domains is the asymmetrical oval in each month, and the vertical direction of the ship domain is parallel to the heading direction of the target ship. The larger the target ship, the larger the size of the ship domain, the greater the grid density of areas around the ship domain, and the larger the high-density area around the ship domain. It shows that sailing larger ships are more easily impacted by other ships than sailing a smaller ship because of other ships should spend more time to follow, encounter, and overtake the target ship. The other ships sailed on the left side of the target ship when encountering the target ship. The other ships should sail to the right side of the target ship and overtake the target ship. Because of different ship maneuvering behaviors on the sides of target ship, the grid densities between the left side of ship domain and the right side of ship domain have obvious differences.

The inland ships are divided into the upbound ship and the downbound ship based on the relationships between ship heading and direction of flow. The ship domains of upbound ships and downbound ship were established in January, February, July, and August in 2014. The ship domain of upbound ships and downbound ships in January is shown in Figures 12 and 13, respectively. Ship domains in other months are shown in the Appendix B. 

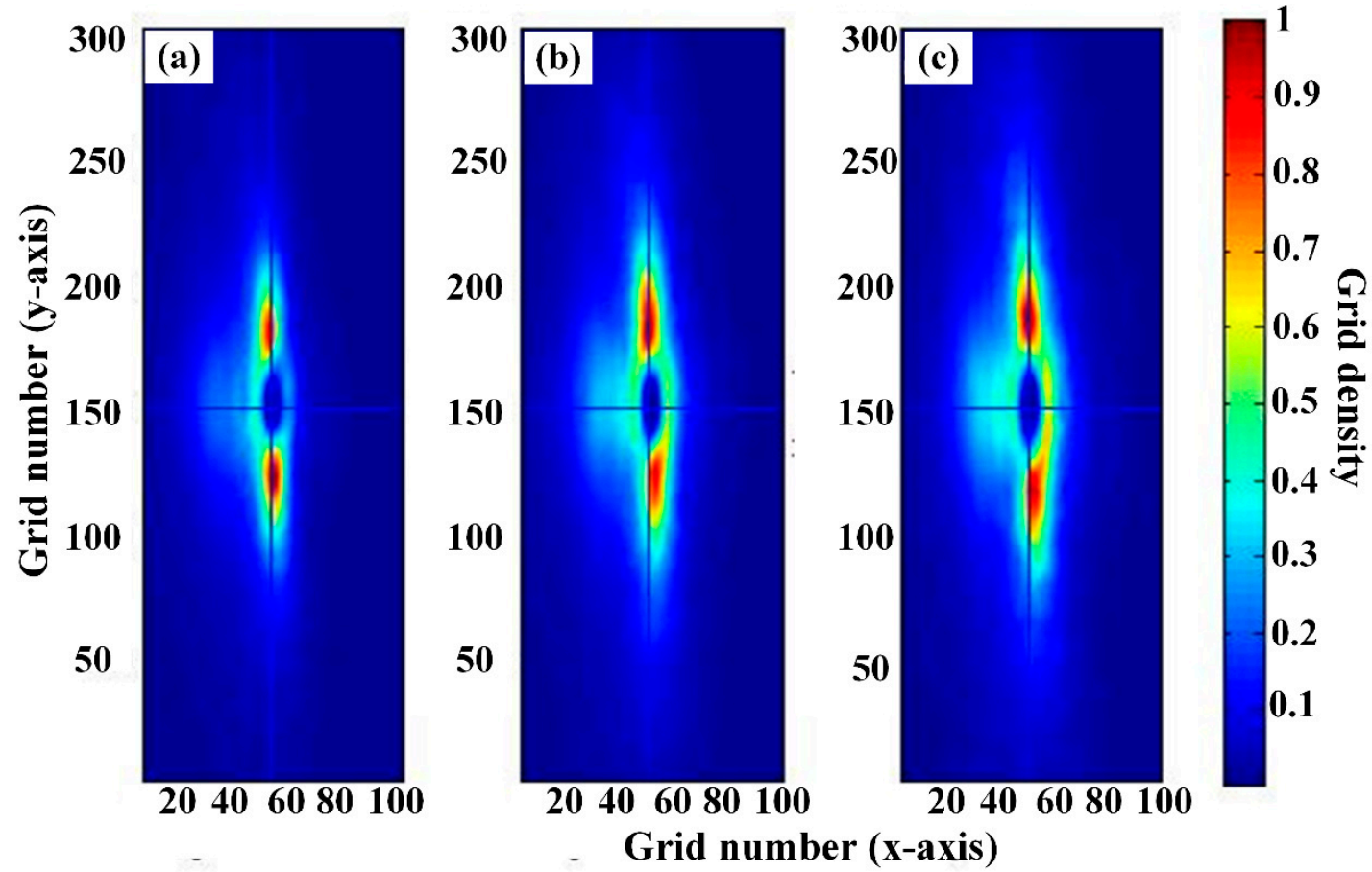

Figure 12. Ship domains of different types of the upbound ship in January 2014. (a-c) represent the ship domain of ships with 60-79 m length, 80-99 m length, and 100-120 m, respectively.

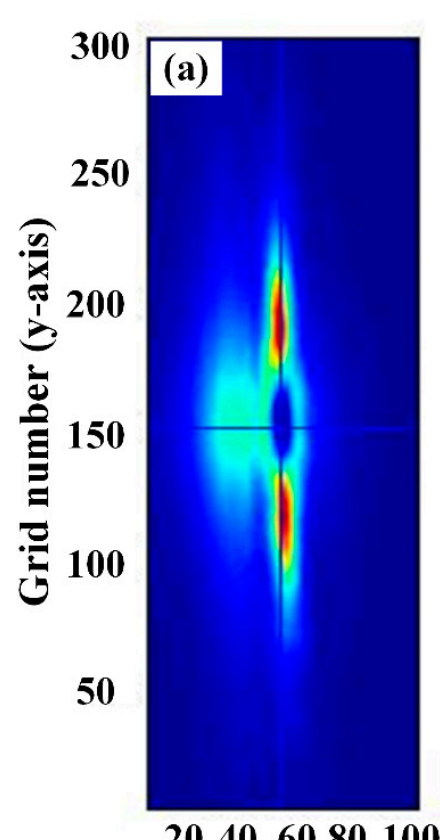

20406080100

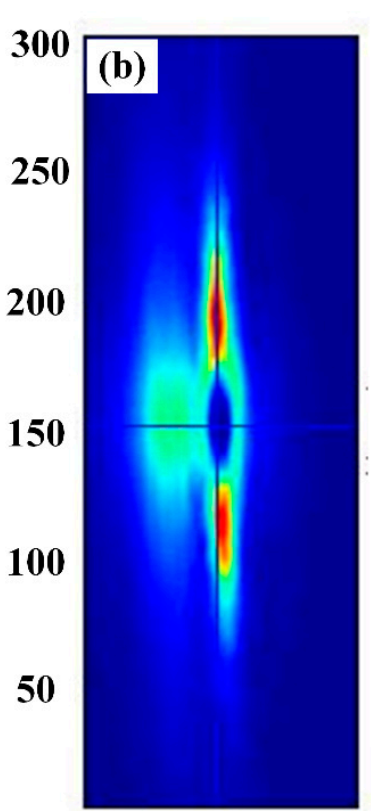

20406080100

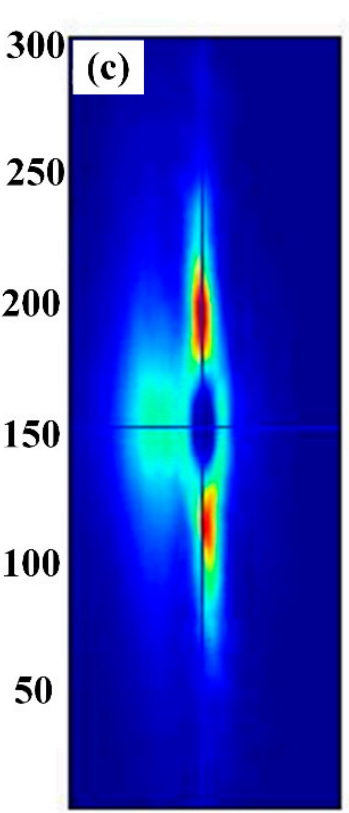

20406080100

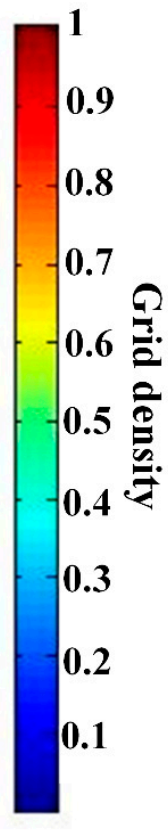

Grid number (x-axis)

Figure 13. Ship domains of different types of the downbound ship in January 2014. (a-c) represent the ship domain of ships with 60-79 m length, 80-99 m length, and 100-120 m, respectively.

\subsubsection{Ship Domains Analysis}

In Section 4.2.1, the grid density maps of three types of ship are calculated, and the ship domains can be established. From the density maps, we can see that the critical density causing the change between the mesh color of the ship domain and the nonship domain is about 0.2 . Therefore, the cross-section image is segmented with a threshold value of $20 \%$ of 
the maximum density value [39] According to measure the distance between two points which are the intersection points of the cross line and the grid, the length of ship domain and the width of ship domain can be calculated, and then the relationships between the ship size and the domain size can be analyzed. The grid density data in January is taken as an example to product the cross-section image, which is shown in Figure 14. Figure 14a indicates three columns of grid density data in the direction of longitudinal axis of the ship center, and Figure 14b indicates three rows of grid density data in the direction of horizontal axis of the ship center. The blue straight lines are the cutting lines in Figure 14a,b.

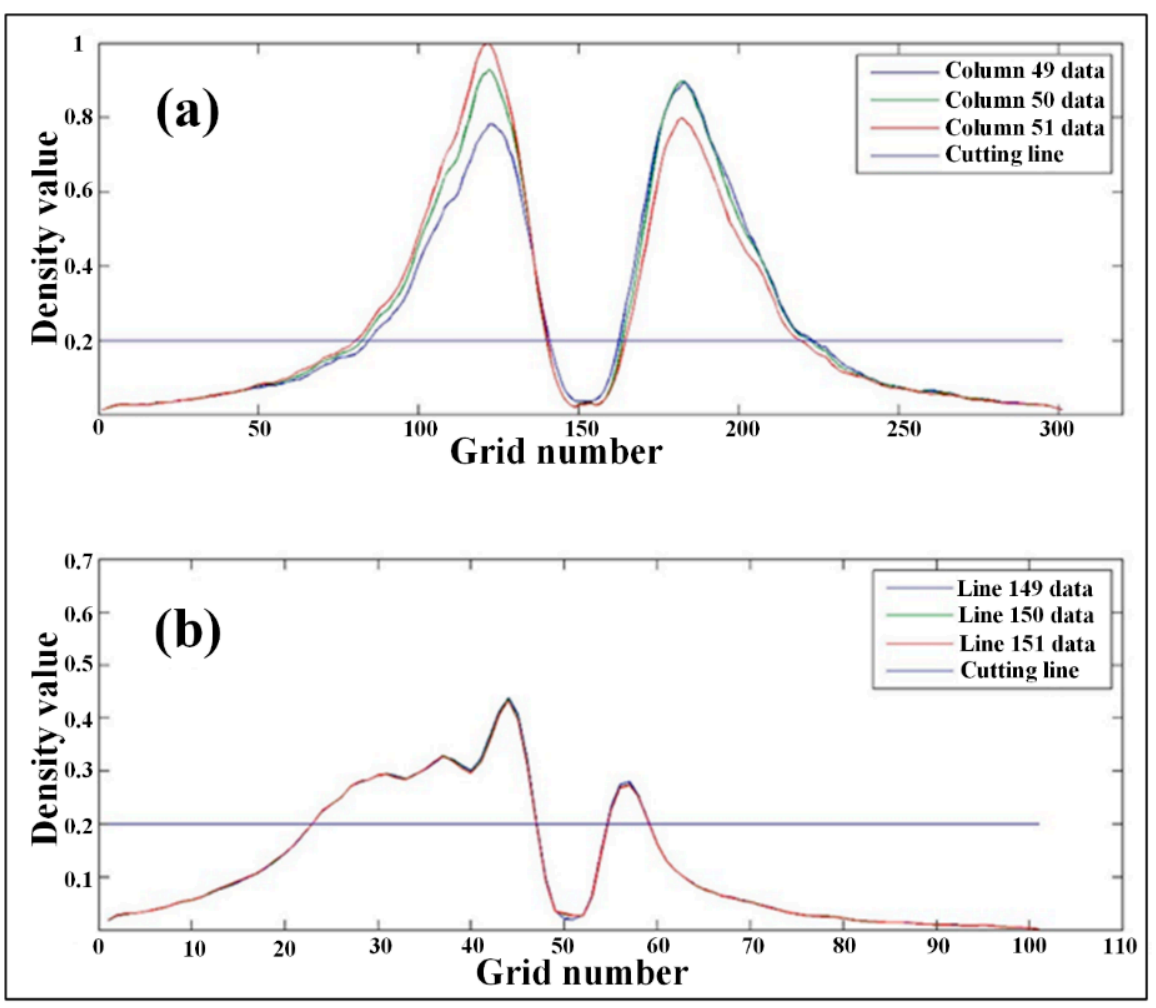

Figure 14. The cross-section diagrams of ship domain (the ship length in the range of 60-79 $\mathrm{m}$ ) in January. (a) is in the direction of $y$-axis, and (b) is in the direction of $x$-axis.

Based on the grid density maps, the cross-section images of domains of three kinds of ship in January are presented in Figure 15, and the other months (February, July, and August) are presented in the Appendix C. Due to the influences of the separate navigation system in the bridge area, there are more ships that come from portside than other directions. This phenomenon causes the density value on the left of the three kinds of grids density map to be higher than that on the right. The ranges of the high-density areas on the left of the three kinds of grids density map in July and August, that is, the ship encountering area, are significantly greater than the one in January and February, which corresponds to the situation that the water level in July and August is higher than the water level in January and February, and the corresponding navigation area becomes wider.

The domain sizes of three kinds of ship in four months are calculated, and the results are shown in Table 1. Considering the heading direction, the domain sizes of upbound ships and downbound ships in four months are shown in Table 2.

From the results of the size of the domain in four months, the ratio of the domain's size to the ship's size in each month is obtained in Table 3. 

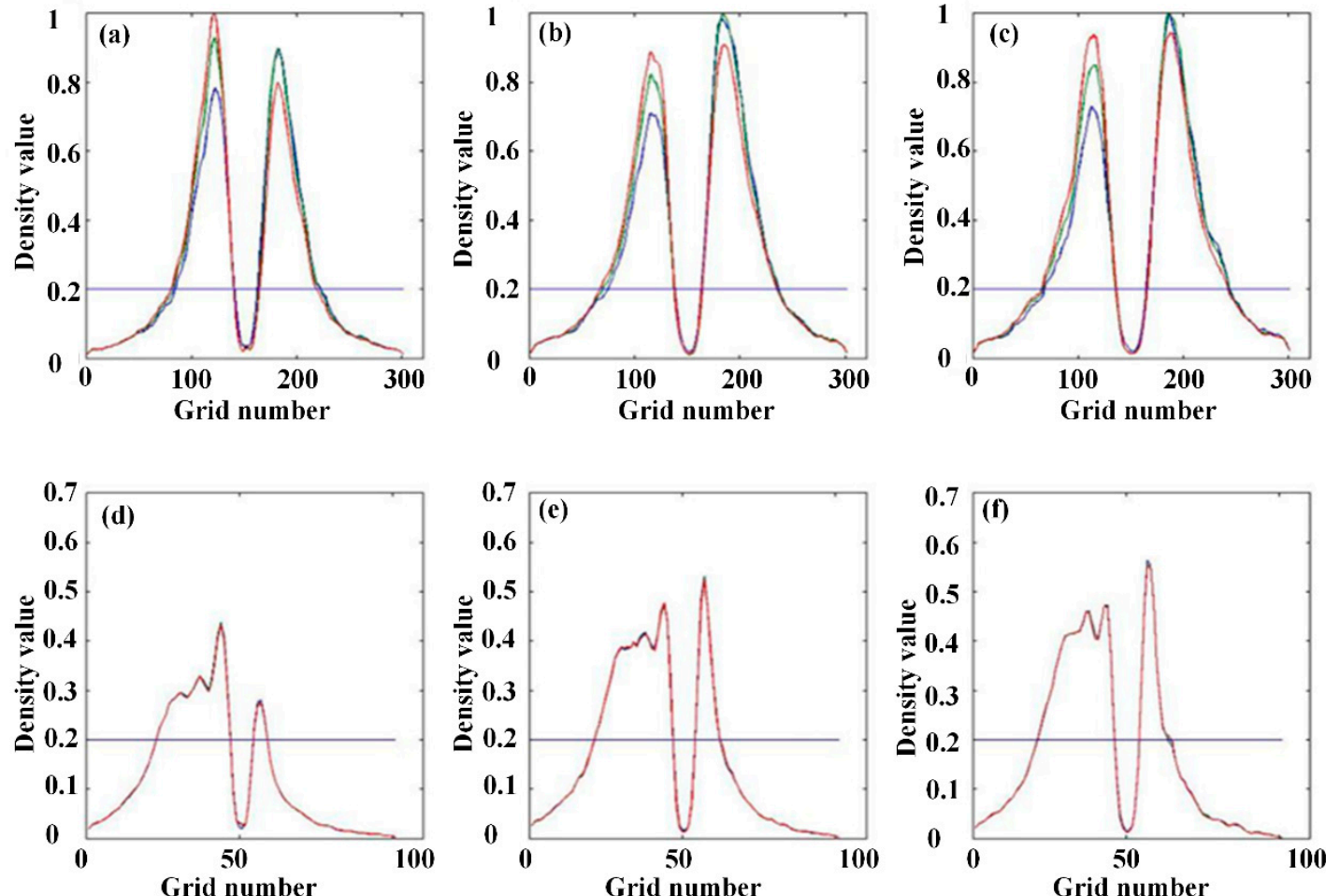

Figure 15. The cross-section diagram of three kinds of ship in the direction of $y$-axis and the direction of $x$-axis in January. (In the figure, (a-c) denotes the long axis section of the domains of ships in 60-80, 80-100, and 100-120 m, respectively. (d-f) denotes the short axis section of the domains of ships in 60-80, 80-100, and 100-120 m, respectively).

Table 1. The size of domain of three types of ship in four months in 2014.

\begin{tabular}{ccccccc}
\hline & \multicolumn{3}{c}{ Length of Domain } & \multicolumn{3}{c}{ Width of Domain } \\
\cline { 2 - 7 } & $\mathbf{6 0 - 7 9} \mathbf{~}$ & $\mathbf{8 0 - 9 9} \mathbf{~ m}$ & $\mathbf{1 0 0 - 1 2 0 ~} \mathbf{~}$ & $\mathbf{6 0 - 7 9} \mathbf{~}$ & $\mathbf{8 0 - 9 9} \mathbf{~}$ & $\mathbf{1 0 0 - 1 2 0 ~} \mathbf{~}$ \\
\hline January & 280 & 300 & 330 & 90 & 90 & 100 \\
February & 290 & 310 & 380 & 100 & 100 & 110 \\
July & 210 & 220 & 230 & 80 & 90 & 90 \\
August & 250 & 270 & 300 & 90 & 100 & 100 \\
\hline
\end{tabular}

Table 2. The size of domain of the three types of upbound ship and downbound ship in four months in 2014.

\begin{tabular}{lcccccc}
\hline & \multicolumn{2}{c}{ Length of Domain of Upbound Ship } & \multicolumn{3}{c}{ Length of Domain of Downbound Ship } \\
\cline { 2 - 7 } & $\mathbf{6 0 - 7 9} \mathbf{~ m}$ & $\mathbf{8 0 - 9 9} \mathbf{~ m}$ & $\mathbf{1 0 0 - 1 2 0 ~} \mathbf{m}$ & $\mathbf{6 0 - 7 9} \mathbf{~ m}$ & $\mathbf{8 0 - 9 9} \mathbf{~ m}$ & $\mathbf{1 0 0 - 1 2 0 ~} \mathbf{~}$ \\
\hline January & 250 & 260 & 300 & 310 & 350 & 380 \\
February & 260 & 270 & 270 & 330 & 360 & 400 \\
July & 200 & 210 & 220 & 340 & 340 & 400 \\
August & 220 & 240 & 250 & 330 & 330 & 380 \\
\hline
\end{tabular}

Table 3. The ratio of the domain's size to the ship's size in each month.

\begin{tabular}{lcccc}
\hline \multicolumn{1}{c}{ Month } & January & February & July & August \\
& & & & \\
\hline The Ratio & $3.1 \sim 4.0$ & $3.5 \sim 4.2$ & $2 \sim 2.9$ & $2.8 \sim 3.7$ \\
Width of domain to ship length & $0.9 \sim 1.3$ & $1 \sim 1.5$ & $0.8 \sim 1.2$ & $0.9 \sim 1.3$ \\
Length of domain to ship width & $18.6 \sim 23$ & $21.2 \sim 23.9$ & $12.3 \sim 15.0$ & $16.7 \sim 18.7$ \\
Width of domain to ship width & $5.6 \sim 7.4$ & $6.1 \sim 8.3$ & $5.0 \sim 6.0$ & $5.5 \sim 6.8$ \\
\hline
\end{tabular}


In each month, the ratio of the domain's size to the ship's size is reduced gradually with ship size increases. The length of target ship is recorded as $x_{1}$, the width of target ship is recorded as $x_{1}$, the length of ship domain is recorded as $y_{1}$, and the width of ship domain is recorded as $y_{2}$. The linear fitting method is utilized to explore the linear relationships between the $x_{1}, x_{2}$ and the $y_{1}, y_{2}$, and the fitting results between them in January, February, July, and August are shown the Equations (1)-(4), respectively. The fitting lines between them in January, February, July, and August are shown in the Appendix D.

$$
\begin{gathered}
\left\{\begin{array}{l}
y_{1}=1.3541 x_{1}+184.6778 \\
y_{2}=0.2762 x_{1}+69.1340 \\
y_{1}=8.9665 x_{2}+169.6293 \\
y_{2}=1.8348 x_{2}+65.9741
\end{array}\right. \\
\left\{\begin{array}{l}
y_{1}=2.4084 x_{1}+115.3251 \\
y_{2}=0.2692 x_{1}+79.7069 \\
y_{1}=15.9462 x_{2}+88.2251 \\
y_{2}=1.7863 x_{2}+76.6233
\end{array}\right. \\
\left\{\begin{array}{l}
y_{1}=0.5306 x_{1}+163.4430 \\
y_{2}=0.2614 x_{1}+63.7310 \\
y_{1}=4.2891 x_{2}+144.0638 \\
y_{2}=1.8907 x_{2}+57.6014
\end{array}\right. \\
\left\{\begin{array}{l}
y_{1}=1.3240 x_{1}+157.1640 \\
y_{2}=0.2598 x_{1}+73.8688 \\
y_{1}=10.7747 x_{2}+107.6973 \\
y_{2}=1.8435 x_{2}+68.3266
\end{array}\right.
\end{gathered}
$$

In Appendix D, Figures A13-A16 show that there are obviously differences of the ship domain size between different months. For a ship, the size of ship domain in the dry seasons is larger than the ship domain size in the wet seasons. The size of the ship domain increases with ship size in the same month.

In the selected research waters, the ship flow rate under the dry season is less than that under the wet season in the same segment. Although the rise of the water level in the wet season is obvious, the channel becomes wider and the navigable waters of the ship become larger, the growth degree is less than the increase of the ship flow rate, making the ship density under the dry season is less than that under the wet season in the same segment.

The size and area of the domain of the ships within the same length range under the January and February are significantly greater than that in July and August, as shown in Figure 16, which corresponds to the situation that the ship density in the dry season (January and February) is smaller than that in the wet season (July and August); the size and area of the domain of the upbound ships within the same length range under the January and February are significantly greater than that in July and August, as shown in Figures 17 and 18, which corresponds to the situation that the upbound resistance is smaller, the ship's speed is relatively faster, and the size of the domain is relatively larger. 

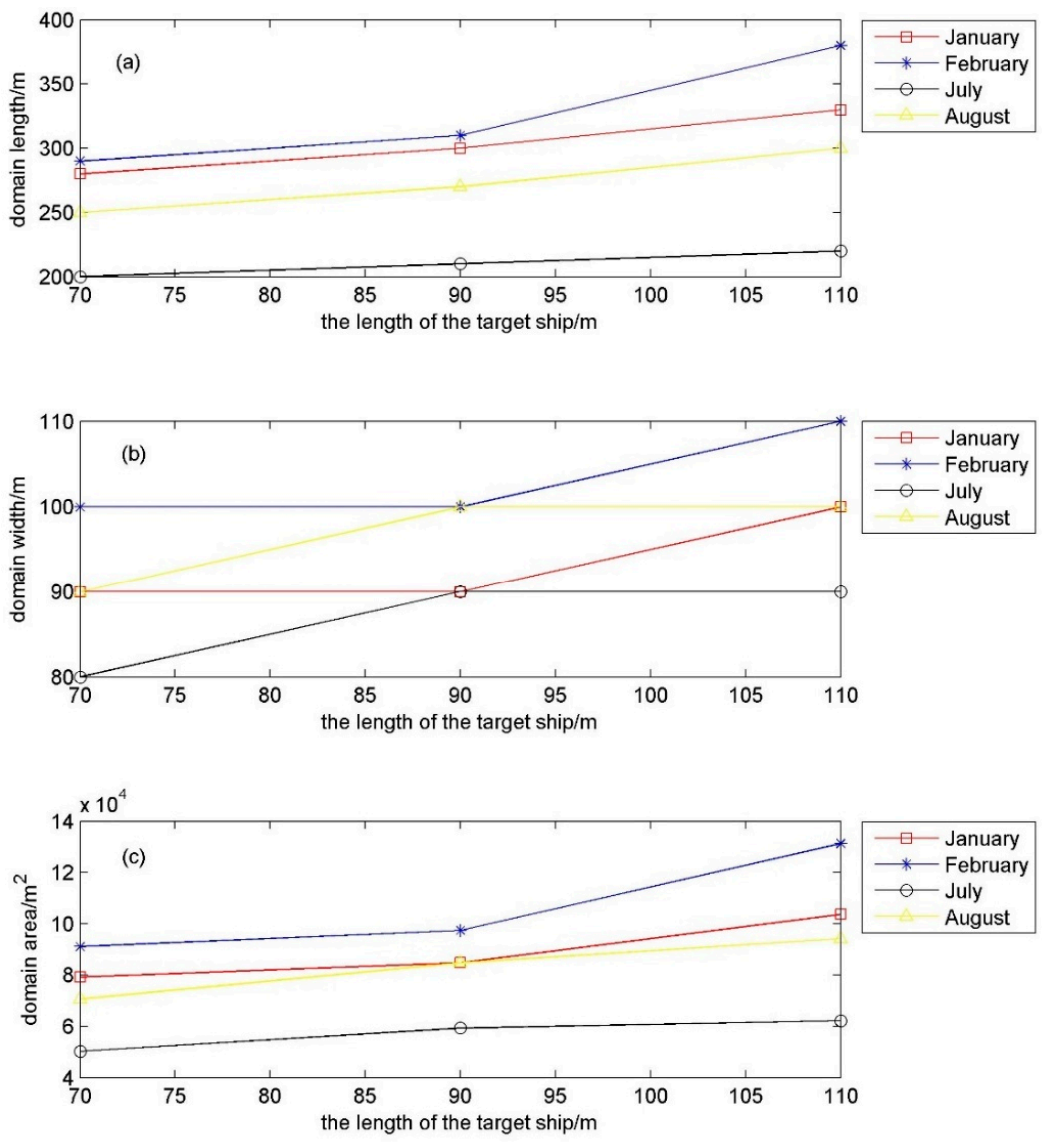

Figure 16. Comparison of the size and area of the ship domain in four months. (a-c) represent the variation of ships with 60-79 m length, 80-99 m length, and 100-120 m, respectively.

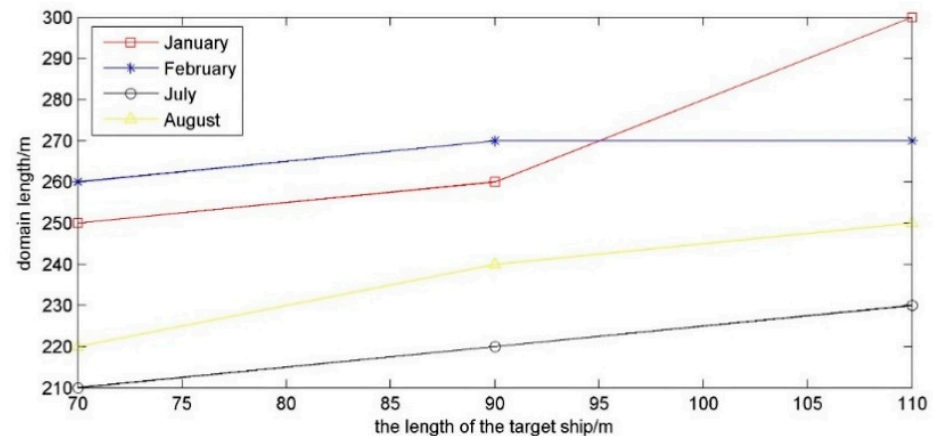

Figure 17. Comparison of the length of the upbound ship domain in four months.

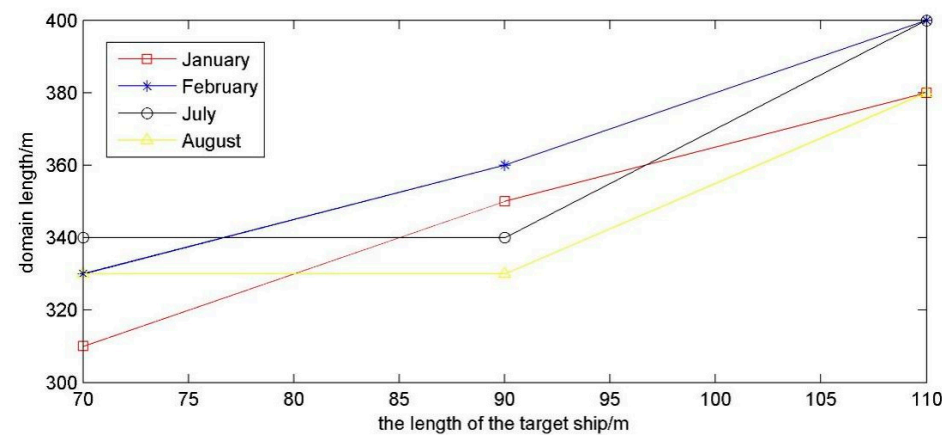

Figure 18. Comparison of the length of the downbound ship domain in four months. 


\section{Discussion}

A spatiotemporal statistical analysis method establishment method of ship domain in inland waters is proposed and tested in the Yangtze River. Ships are divided into three types based on the ship size. Based on the dynamic AIS data, establishing ship domains of different types of ships in different navigational environments and analyzing the relationships between the inland ship domains with ship size, water level, and the navigating characteristics of inland ships. Previously, the proposed method and experimental results enrich the analysis dimension of inland waters ship domain, and there also are some limitations of the proposed method.

The AIS data of ships have some abnormal and missing values due to the influence of the inland navigation environments on the inland ship's AIS equipment signals. The data are preprocessed by data elimination and interpolation to conduct the statistical modeling analysis, which can reduce the impact on the analysis results to some extent, but the shortcomings of the source data still essentially affect the realities of the acquired ship domain results.

Only the ship's AIS data under the four months in the typical inland waterway are selected to carry out the statistical analysis and comparison. Therefore, the conclusion of seasonal differences is not convincing enough. More monthly data will be selected to study the ship domain's characteristics in the future.

In this paper, we divide ships into three types by ship's length with a delta $20 \mathrm{~m}$. Such a classification rule needs further validation to be truly representative of the distribution characteristics of the inland river ship's length and the ship's length influences on the domain of the inland water vessels. In future works, a more scientific classification standard needs to be established.

The ships are only classified by length, meaning only the influence of the ship's length is considered on the domain of the inland waters. In future research, the ships can be classified according to speed, type, navigational environment, and other factors.

The results of this work show that there are obvious differences of the ship domain in the inland waters on the time scales. The results not only enrich the theory of the water traffic flow but also have certain reference value for the Yangtze River main line traffic management department in formulating more scientific regulation of ships.

\section{Conclusions}

In this work, a spatiotemporal statistical analysis method of ship domain in inland waters is proposed. The dynamic grid densities of ships in each moment are calculated to determine and analyze the shape and size of ship domain of different types of ships. The Wuhan section of the Yangtze River as a typical inland water is selected as the experimental area to test the feasibility of the proposed method and to analyze the characteristics of ship domains of different type of ships in different navigational environments in inland waters.

Analyzing the attributes data of ships, ships can be divided into three categories based on ship length: 60-79, 80-99, and 100-120 $\mathrm{m}$ in the experimental waters. The water levels data of the Yangtze River in 2014 shows that the dry seasons are January and February, and the wet seasons are July and August in the Yangtze River. Ship activity data in the dry seasons and wet seasons in Wuhan section of the Yangtze River are selected to develop the dynamic grid density dataset and grid density maps. The grid density dataset is statistical analyzed to establish ship domains of different categories of ships in dry seasons and wet seasons. The experimental results show that all ship domains look like a asymmetric ellipse and the long axis of the ellipse is parallel to the heading of ship. The ship domain extends as the ship length increases. The navigational environments and the navigational rules in inland waters have significant influences on ship domains, and the sizes of ship domains of the same category ships in the dry seasons are obviously greater than in the wet seasons, and the left areas of ships encounter areas in the dry seasons are smaller than in the wet seasons. 
The activity characteristics of ships and the navigational environments have obvious differences between ships in inland waters and ships in other waters, i.e., in open waters, in restricted waters, and at sea; therefore, the ship domains have significant differences between them. Establishing reliable ship domains in inland waters are beneficial for making ship collision avoidance decisions for deck officers.

Author Contributions: Conceptualization, F.Z., X.P. and Y.W.; Data curation, F.Z. and H.Z.; Formal analysis, L.H.; Funding acquisition, L.H. and Y.W.; Methodology, M.Z.; Project administration, Y.W.; Validation, H.Z.; Visualization, L.H.; Writing—original draft, X.P.; Writing—review \& editing, X.P. All authors have read and agreed to the published version of the manuscript.

Funding: This research was funded by the National Key R\&D Program of China, grant number 2018YFC1407405 and 2018YFC0213904, and the National Science Foundation of China, grant number 41801375 .

Institutional Review Board Statement: Not applicable.

Informed Consent Statement: Not applicable.

Data Availability Statement: Some or all data, models, or code that support the findings of this study are available from the corresponding author upon reasonable request.

Acknowledgments: This work was supported by the National Key R\&D Program of China (Grant No. 2018YFC1407405), the National Key R\&D Program of China (Grant No. 2018YFC0213904) and the National Science Foundation of China (Grant No. 41801375).

Conflicts of Interest: The authors declare no conflict of interest.

\section{Appendix A}
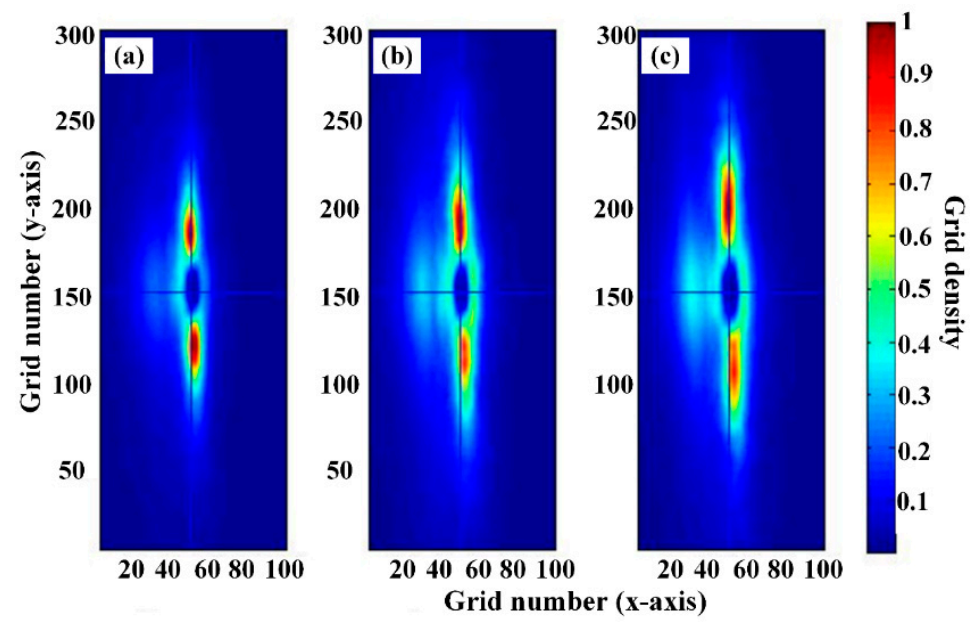

Figure A1. The ship domain of different types of ship in February 2014. (a-c) represent the ship domain of ships with 60-79 m length, 80-99 m length, and 100-120 m, respectively. 

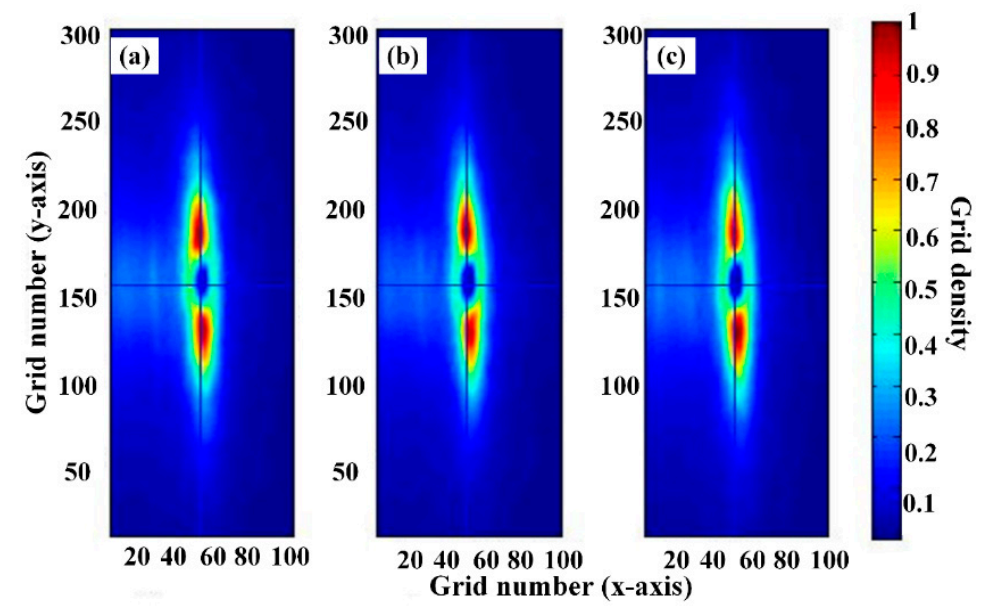

Figure A2. The ship domain of different types of ship in July 2014. (a-c) represent the ship domain of ships with 60-79 m length, 80-99 m length, and 100-120 m, respectively.
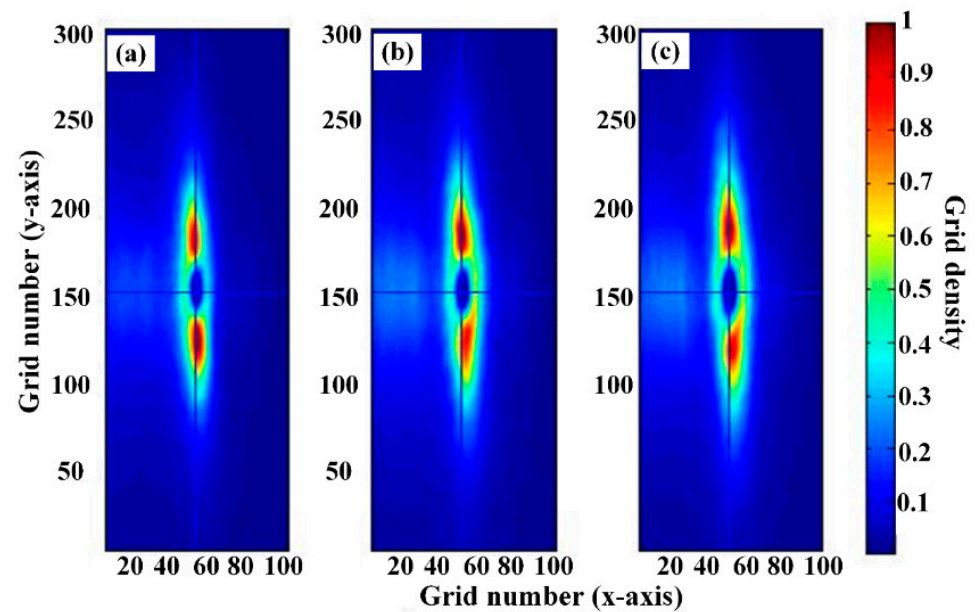

Figure A3. The ship domain of different types of ship in August 2014. (a-c) represent the ship domain of ships with 60-79 m length, 80-99 m length, and 100-120 m, respectively.

Appendix B
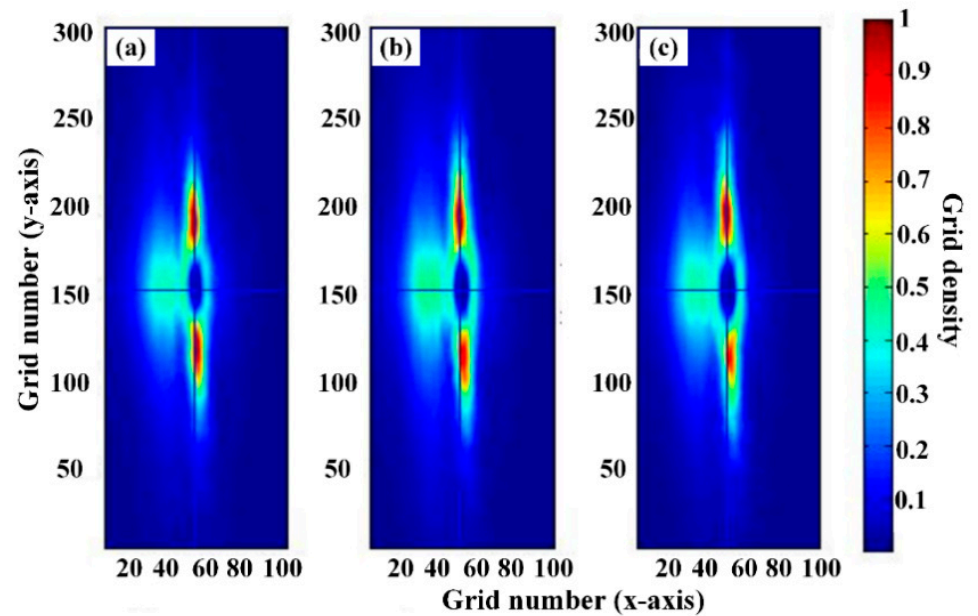

Figure A4. Ship domains of different types of the upbound ship in February 2014. (a-c) represent the ship domain of ships with 60-79 m length, 80-99 m length, and 100-120 m, respectively. 

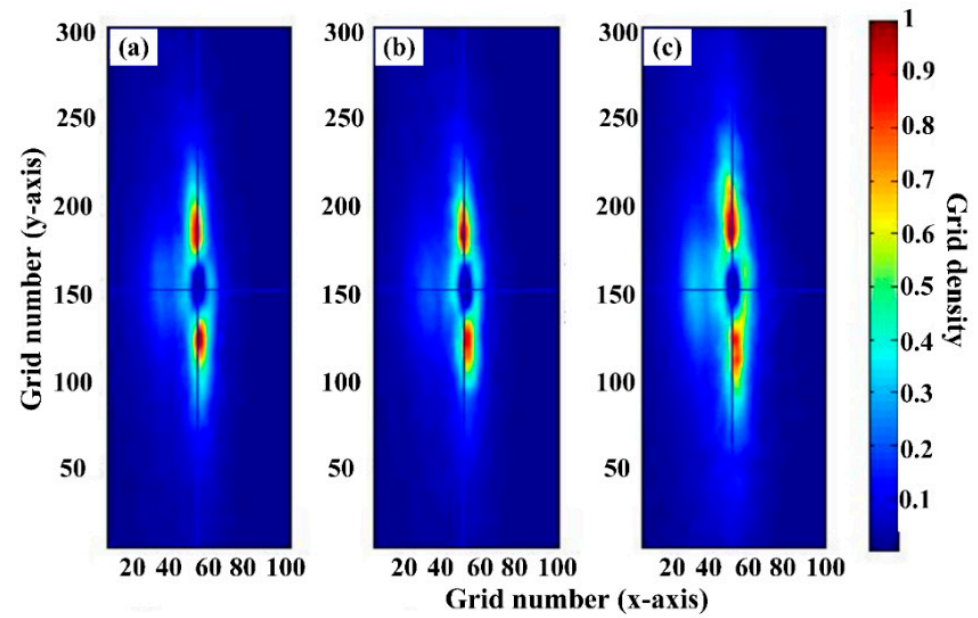

Figure A5. Ship domains of different types of the downbound ship in February in 2014. (a-c) represent the ship domain of ships with 60-79 m length, 80-99 m length, and 100-120 m, respectively.
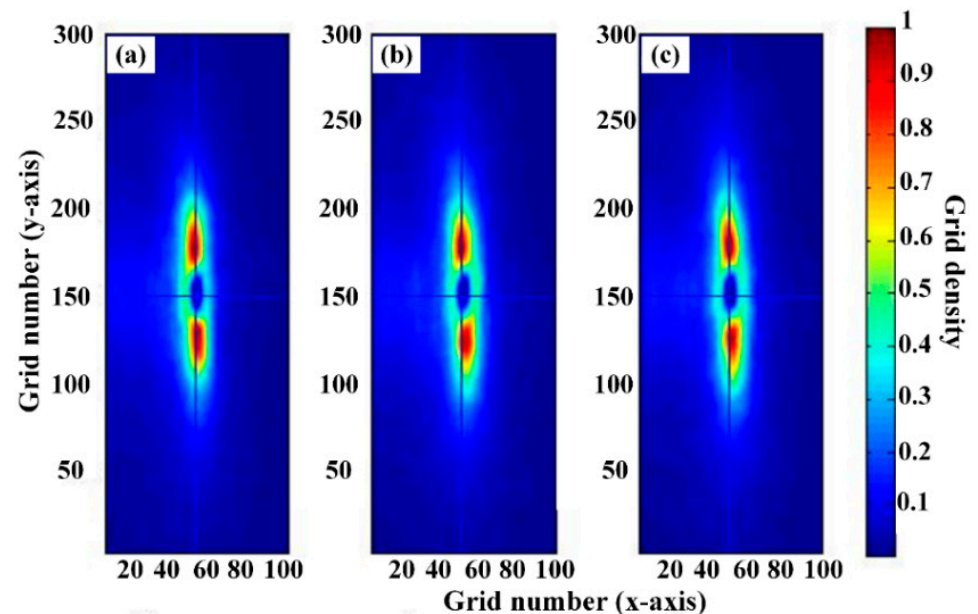

Figure A6. Ship domains of different types of the upbound ship in July 2014. (a-c) represent the ship domain of ships with 60-79 m length, 80-99 m length, and 100-120 m, respectively.
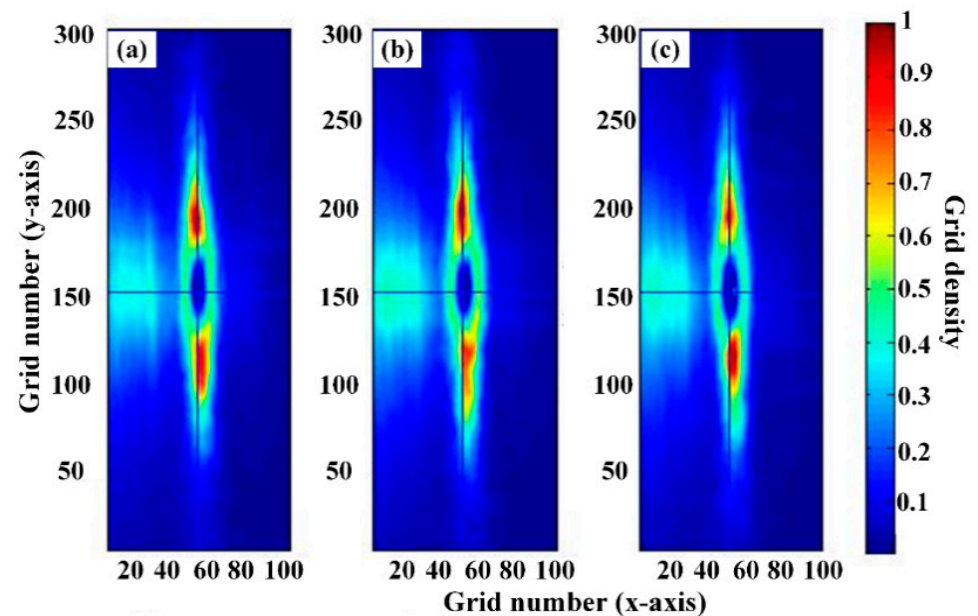

Figure A7. Ship domains of different types of the downbound ship in July 2014. (a-c) represent the ship domain of ships with 60-79 m length, 80-99 m length, and 100-120 m, respectively. 

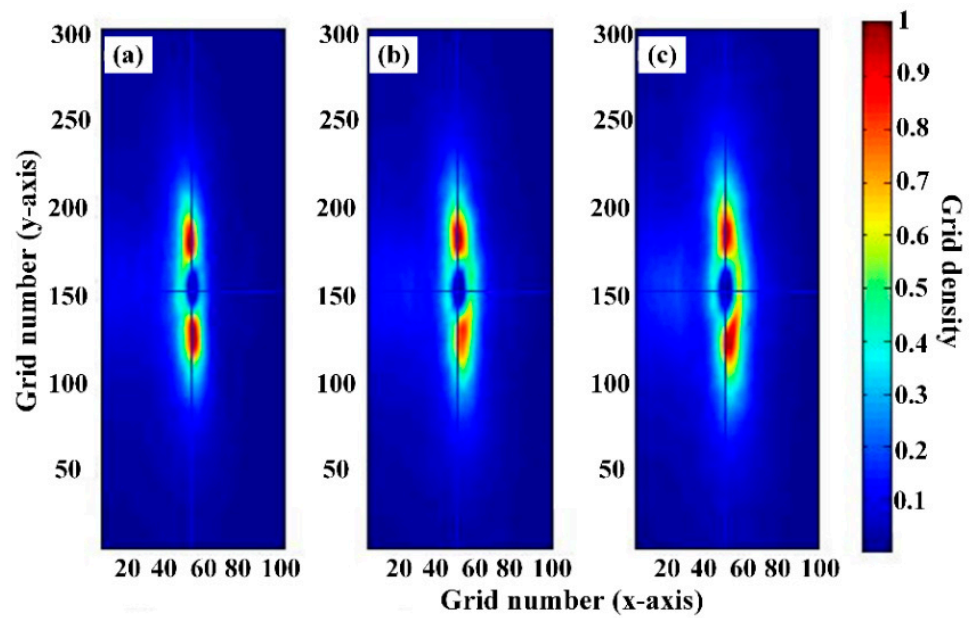

Figure A8. Ship domains of different types of the upbound ship in August 2014. (a-c) represent the ship domain of ships with 60-79 m length, 80-99 m length, and 100-120 m, respectively.
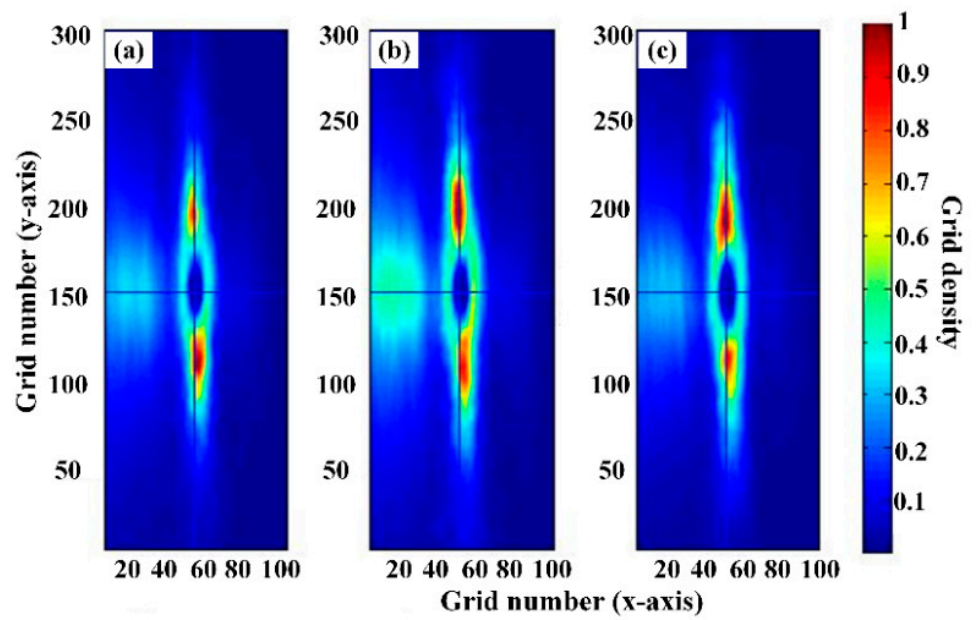

Figure A9. Ship domains of different types of the downbound ship in August 2014. (a-c) represent the ship domain of ships with 60-79 m length, 80-99 m length, and 100-120 m, respectively. 


\section{Appendix C}
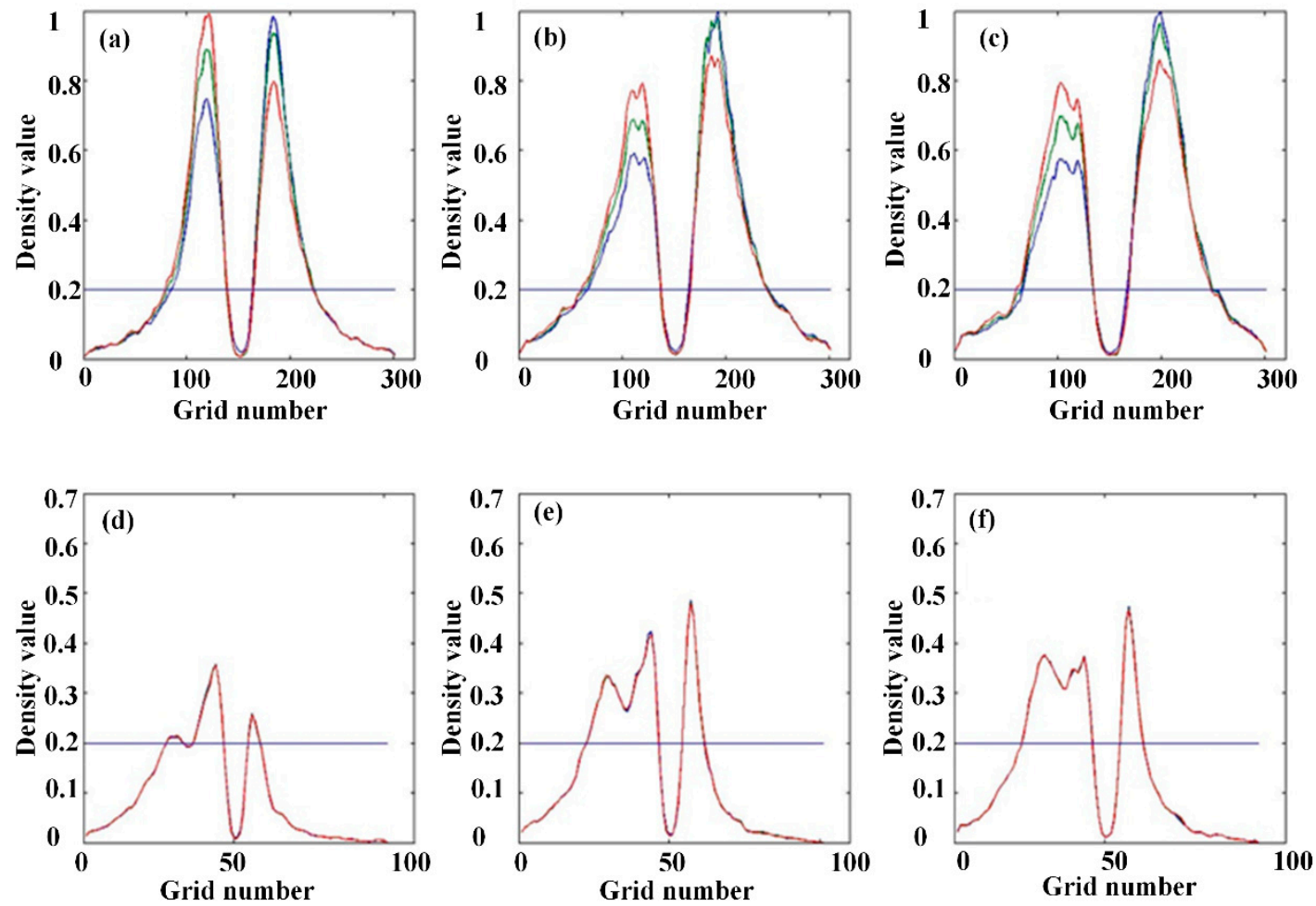

Figure A10. The cross-section diagram of three kinds of ship in the direction of $y$-axis and the direction of $x$-axis in February. (In the figure, (a-c) denotes the long axis section of the domains of ships in 60-80, 80-100, and 100-120 m, respectively. (d-f) denotes the short axis section of the domains of ships in 60-80, 80-100, and 100-120 m, respectively).
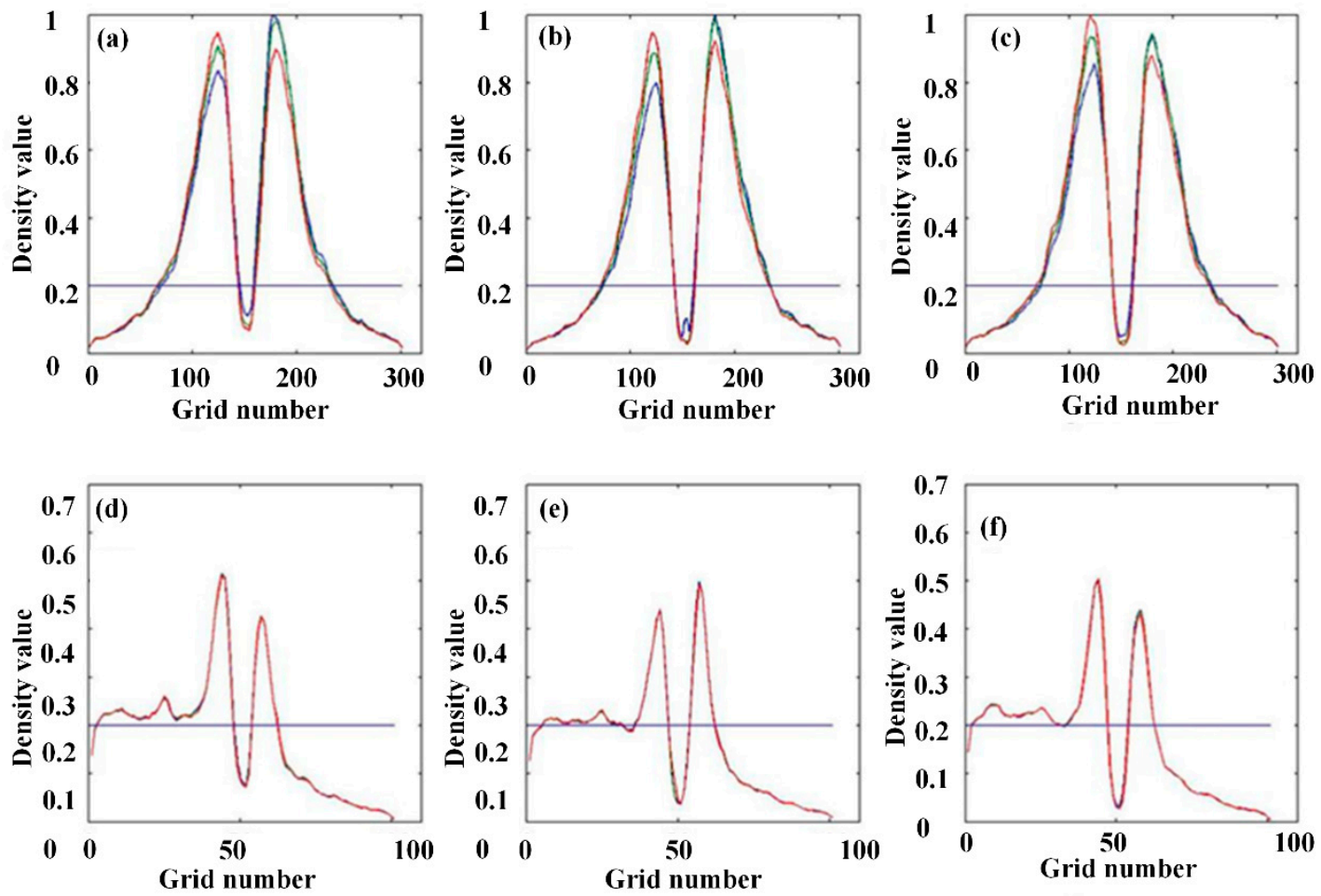

Figure A11. The cross-section diagram of three kinds of ship in the direction of $y$-axis and the direction of $x$-axis in July. (In the figure, $(\mathbf{a}-\mathbf{c})$ denotes the long axis section of the domains of ships in 60-80, 80-100, and 100-120 m, respectively. (d-f) denotes the short axis section of the domains of ships in 60-80, 80-100, and 100-120 m, respectively). 

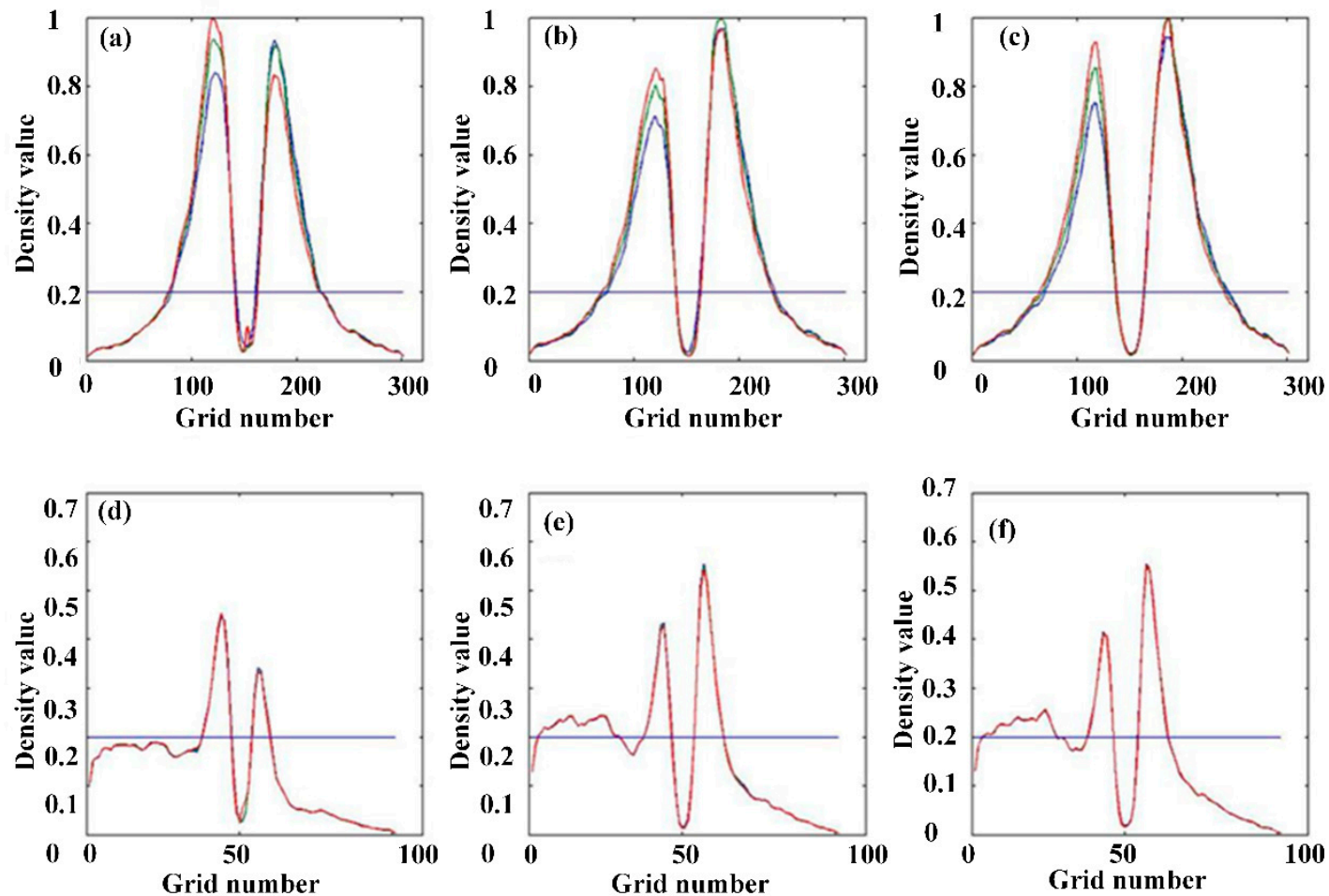

Figure A12. The cross-section diagram of three kinds of ship in the direction of $y$-axis and the direction of $x$-axis in August. (In the figure, (a-c) denotes the long axis section of the domains of ships in 60-80, 80-100, and 100-120 m, respectively. (d-f) denotes the short axis section of the domains of ships in 60-80, 80-100, and 100-120 m, respectively).

\section{Appendix D}
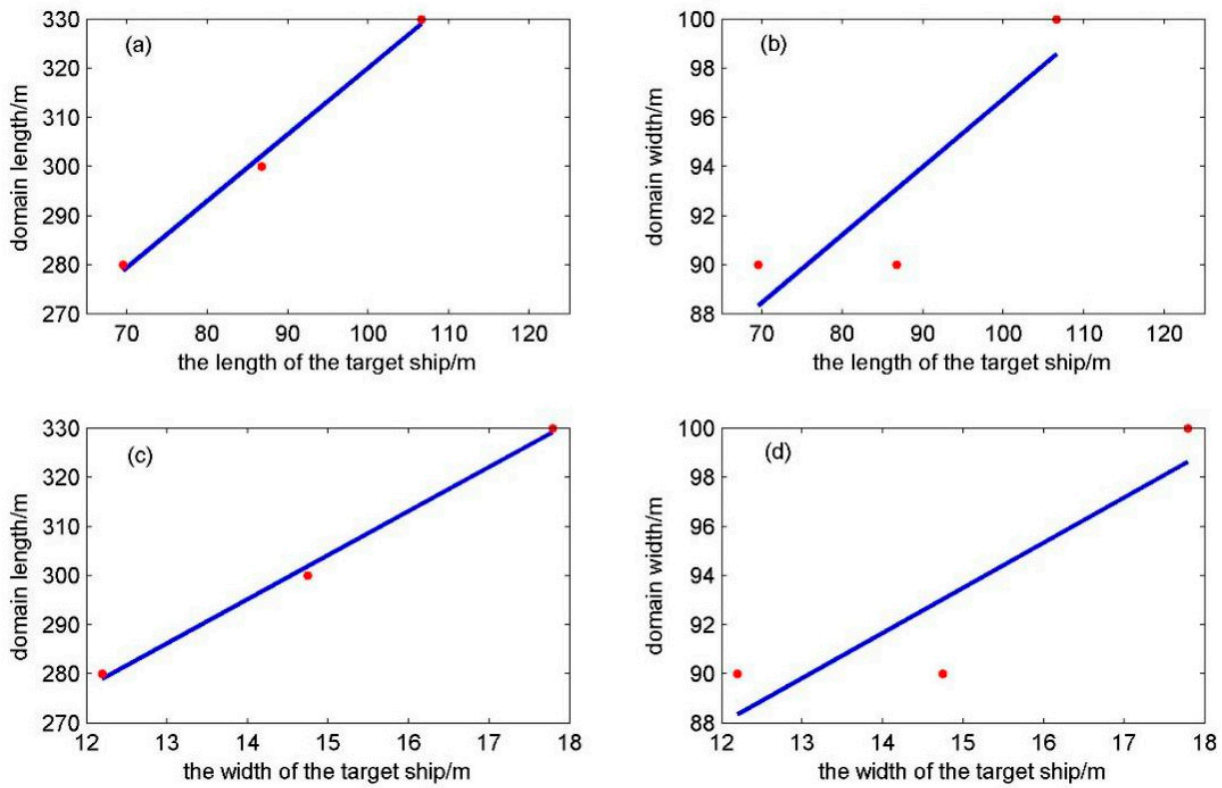

Figure A13. The fitting relationships between the length, width of the domain and the length, width of the ship in January (in the figure, (a-d) denotes the fitting relationship between the ship domain's length and the ship's length, the ship domain's width and the ship's length, the ship domain's length and the ship's width, and the ship domain's width and the ship's width, respectively). 

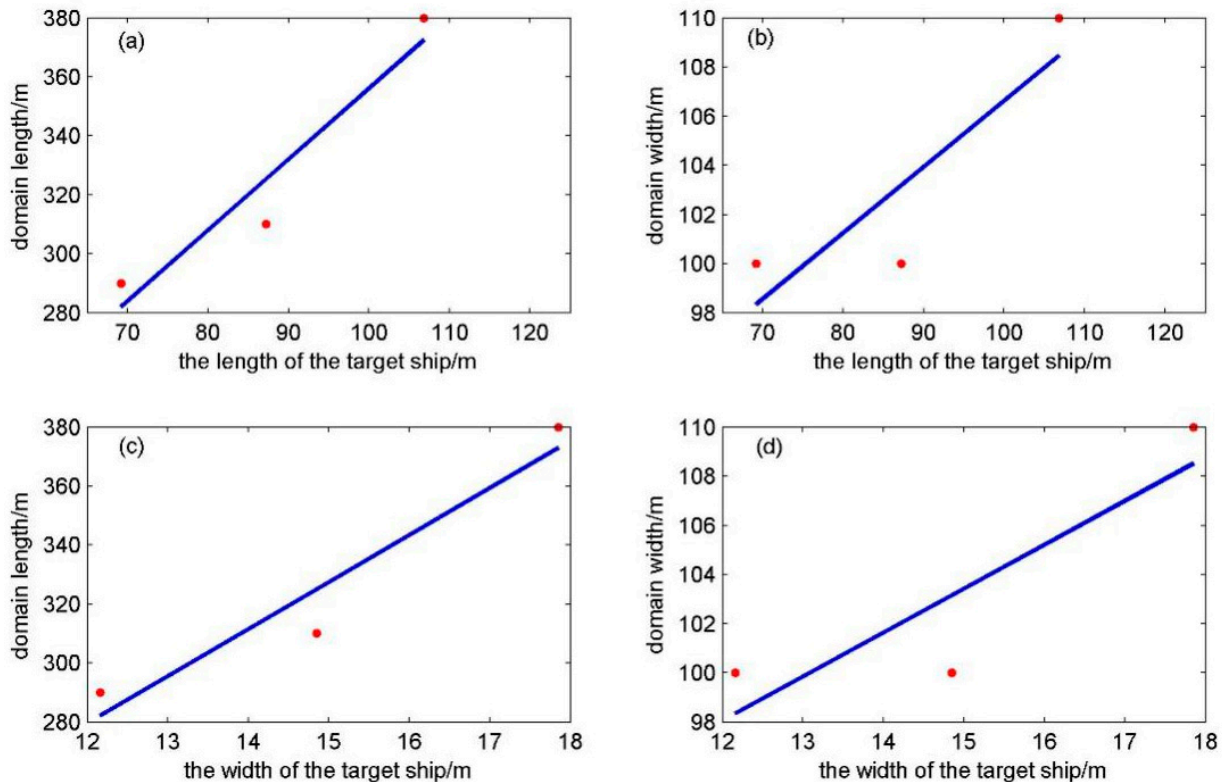

Figure A14. The fitting relationships between the length, width of the domain and the length, width of the ship in February. (In the figure, (a-d) denotes the fitting relationship between the ship domain's length and the ship's length, the ship domain's width and the ship's length, the ship domain's length and the ship's width, the ship domain's width and the ship's width, respectively).
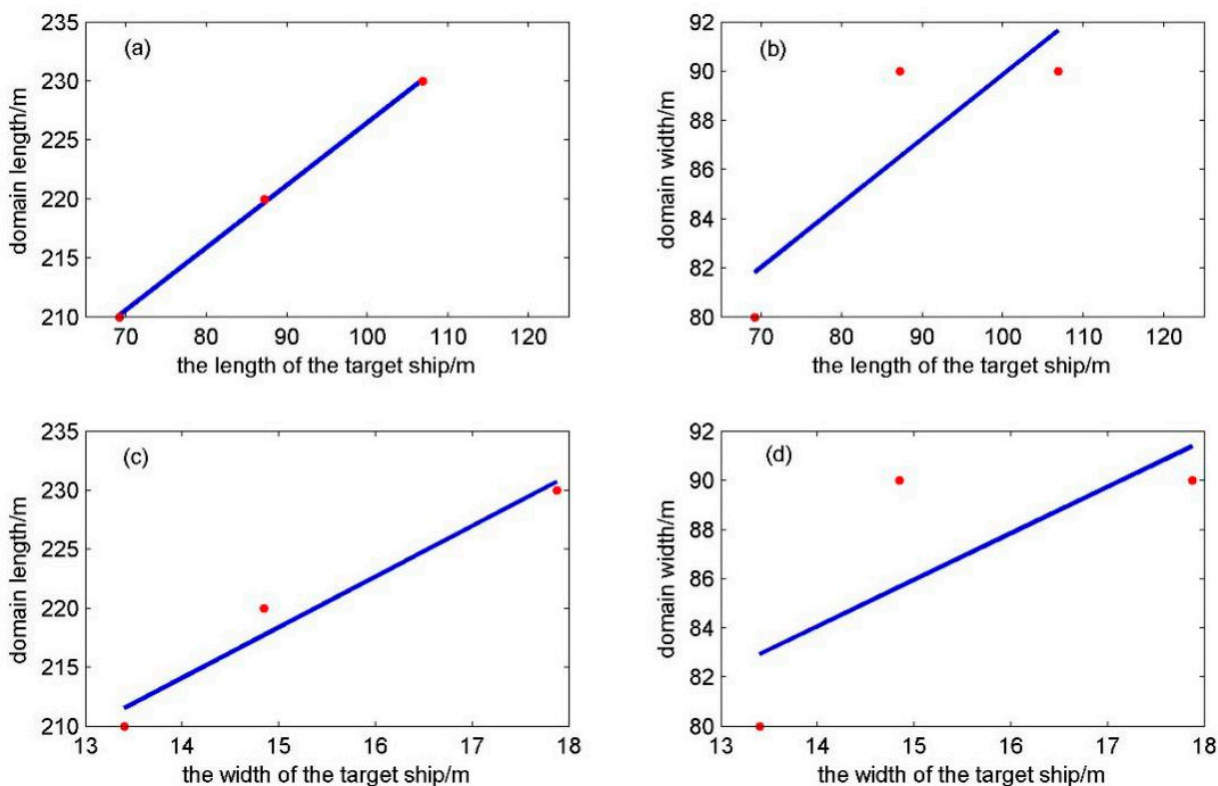

Figure A15. The fitting relationships between the length, width of the domain and the length, width of the ship in July. (In the figure, (a-d) denotes the fitting relationship between the ship domain's length and the ship's length, the ship domain's width and the ship's length, the ship domain's length and the ship's width, the ship domain's width and the ship's width, respectively). 

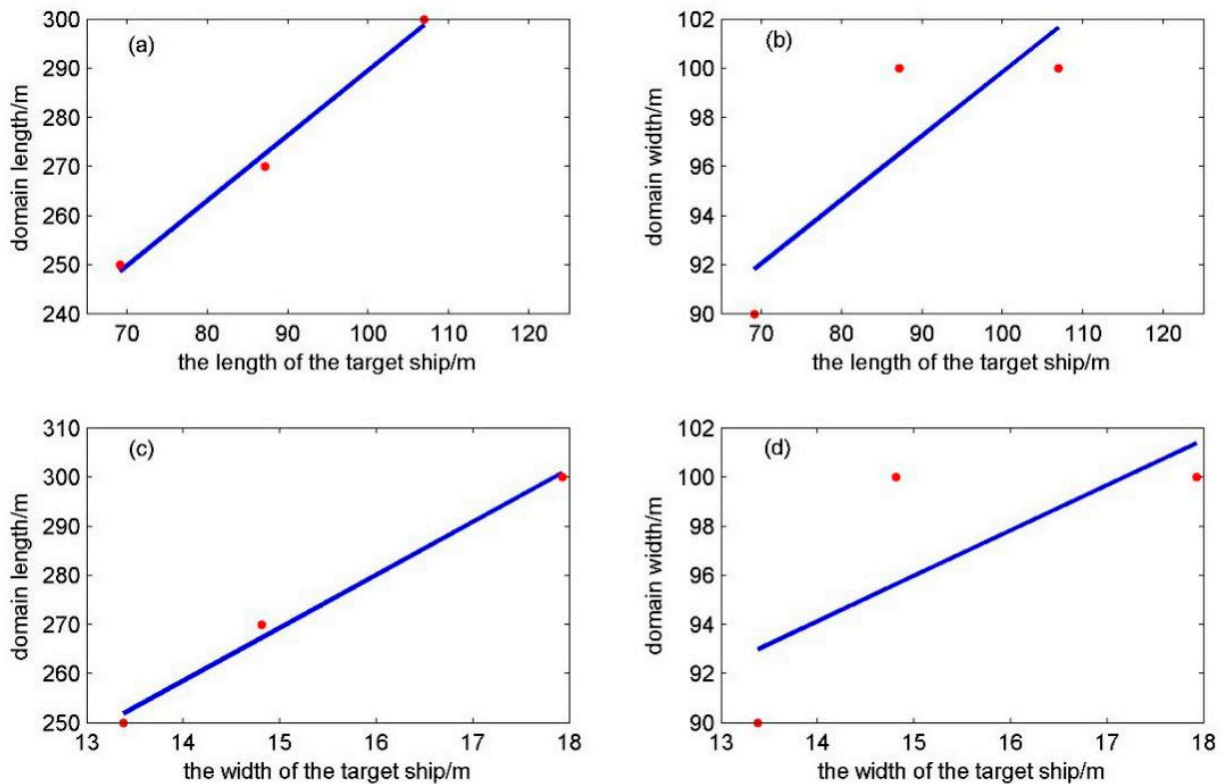

Figure A16. The fitting relationships between the length, width of the domain and the length, width of the ship in August. (a-d) is the fitting relationship between the length of ship domain and the ship length, between the width of ship domain and the ship length, between the length of ship domain and the ship width, and between the width of ship domain and the ship width, respectively).

\section{References}

1. Coldwell, T.G. Marine Traffic Behaviour in Restricted Waters. J. Navig. 1983, 36, 430-444. [CrossRef]

2. Zhang, L.; Meng, Q. Probabilistic ship domain with applications to ship collision risk assessment. Ocean Eng. 2019, 186, 106-130. [CrossRef]

3. Fiskin, R.; Nasiboglu, E.; Yardimci, M.O. A knowledge-based framework for two-dimensional (2D) asymmetrical polygonal ship domain. Ocean Eng. 2020, 202, 107187. [CrossRef]

4. Im, N.K. Potential risk ship domain as a danger criterion for realtime ship collision risk evaluation. Ocean Eng. 2019, 194, 106610. [CrossRef]

5. Szlapczynski, R.; Szlapczynska, J. An analysis of domain-based ship collision risk parameters. Ocean Eng. 2016, 126, 47-56. [CrossRef]

6. Szlapczynski, R.; Szlapczynska, J. Review of ship safety domains: Models and applications. Ocean Eng. 2017, 145C, 277-289. [CrossRef]

7. Fujii, Y. Traffic Capacity. J. Navig. 1971, 24, 543-552. [CrossRef]

8. Wang, N. A Novel Analytical Framework for Dynamic Quaternion Ship Domains. J. Navig. 2013, 66, 265-281. [CrossRef]

9. Goodwin, E.M. A Statistical Study of Ship Domains. J. Navig. 1975, 28, 328-344. [CrossRef]

10. Davis, P.V.; Dove, M.J.; Stockel, C.T.A. Computer Simulation of Marine Traffic Using Domains and Arenas. J. Navig. 1980, 33, 215. [CrossRef]

11. Davis, P.V.; Dove, M.J.; Stockel, C.T.A. computer simulation of multi-ship encounters. J. Navig. 1982, 35, 347-352. [CrossRef]

12. Wang, Y.; Chin, H. An Empirically-Calibrated Ship Domain as a Safety Criterion for Navigation in Confined Waters. J. Navig. 2016, 69, 257-276. [CrossRef]

13. Liu, J.; Zhou, F.; Li, Z.; Wang, M.; Liu, R.W. Dynamic Ship Domain Models for Capacity Analysis of Restricted Water Channels. J. Navig. 2016, 69, 481-503. [CrossRef]

14. Xin, X.R.; Liu, K.Z.; Yang, X.; Yuan, Z.; Zhang, J. A simulation model for ship navigation in the "Xiazhimen" waterway based on statistical analysis of AIS data. Ocean Eng. 2019, 180, 279-289. [CrossRef]

15. Bakdi, A.; Glad, I.K.; Vanem, E.; Engelhardtsen, Ø. AIS-based multiple vessel collision and grounding risk identification based on adaptive safety domain. J. Mar. Sci. Eng. 2020, 8, 5. [CrossRef]

16. Pietrzykowski, Z.; Wielgosz, M. Effective ship domain-Impact of ship size and speed. Ocean Eng. 2021, 219, 108423. [CrossRef]

17. Van der Tak, C.; Spaans, J.A. A Model for Calculating a Maritime Risk Criterion Number. J. Navig. 1977, 30, 287-295. [CrossRef]

18. Kijima, K.; Furukawa, Y. Automatic collision avoidance system using the concept of blocking area. IFAC Proc. Vol. 2003, 36, 223-228. [CrossRef]

19. Kijima, K.; Furukawa, Y. Design of automatic collision avoidance system using fuzzy inference. IFAC Proc. Vol. 2001, 34, 65-70. [CrossRef] 
20. Pietrzykowski, Z. Ship's Fuzzy Domain-A Criterion for Navigational Safety in Narrow Fairways. J. Navig. 2008, 61, 499-514. [CrossRef]

21. Wang, N. An Intelligent Spatial Collision Risk Based on the Quaternion Ship Domain. J. Navig. 2010, 63, 733-749. [CrossRef]

22. Lisowski, J.; Rak, A.; Czechowicz, W. Neural network classifier for ship domain assessment. Math. Comput. Simul. 2000, 51, 399-406. [CrossRef]

23. Zhou, D.; Zheng, Z.Y. Relationship between the ship domain and its influence factors. J. Dalian Marit. Univ. 2016, 42, 25-30.

24. Jia, C.Y. Ship Domain in Congested Water Area. J. Dalian Mar. Coll. 1989, 15, 15-19.

25. Liao, H.S.; Peng, G.J. Research on Evaluation of Ship' s Collision Risk in Narrow Channel. J. Navig. 2003, 1, 48-52.

26. Xu, Z.H.; Mou, J.M.; Ji, Y.Q. A Study of 3D Model of Ship Domain for Inland Waterway. J. Wuhan Univ. Technol. Transp. Sci. Eng. 2004, 28, 380-383.

27. Chen, H.Z.; Guo, G.P. Research of Ship Domain and the Traffic Capacity in Paratactic Bridge Water Area. Ship Ocean Eng. 2008, 37, 113-116.

28. Rawson, A.; Rogers, E.; Foster, D.; Phillips, D. Practical application of domain analysis: Port of London case study. J. Navig. 2014, 67, 193-209. [CrossRef]

29. Xiao, F.; Han, L.; Gulijk, C.V.; Ale, B. Comparison study on AIS data of ship traffic behavior. Ocean Eng. 2015, 95, 84-93. [CrossRef]

30. Zhu, M.; Wuqiang, S.; Axel, H.; Yuanqiao, W.; Changshi, X.; Wei, T. Adaptive modeling of maritime autonomous surface ships with uncertainty using a weighted LS-SVR robust to outliers. Ocean Eng. 2020, 200, 107053. [CrossRef]

31. Hansen, M.G.; Jensen, T.K.; Lehn-Schi, L.T.; Melchild, K.; Rasmussen, F.M.; Ennemark, F. Empirical Ship Domain based on AIS Data. J. Navig. 2013, 66, 931-940. [CrossRef]

32. Zhang, W.; Goerlandt, F.; Kujala, P.; Wang, Y. An advanced method for detecting possible near miss ship collisions from AIS data. Ocean Eng. 2016, 124, 141-156. [CrossRef]

33. Wu, X.; Mehta, A.L.; Zaloom, V.A.; Craig, B.N. Analysis of waterway transportation in Southeast Texas waterway based on AIS data. Ocean Eng. 2016, 121, 196-209. [CrossRef]

34. Zhang, L.; Meng, Q.; Xiao, Z.; Fu, X. A novel ship trajectory reconstruction approach using AIS data. Ocean Eng. 2018, 159, 165-174. [CrossRef]

35. Zhang, L.; Wang, H.; Meng, Q. Big Data-Based Estimation for Ship Safety Distance Distribution in Port Waters. Transp. Res. Rec. J. Transp. Res. Board 2015, 2479, 16-24. [CrossRef]

36. Tu, E.; Zhang, G.; Rachmawati, L.; Rajabally, E.; Huang, G.B. Exploiting AIS Data for Intelligent Maritime Navigation: A Comprehensive Survey. IEEE Trans. Intell. Transp. Syst. 2018, 19, 1559-1582. [CrossRef]

37. Pietrzykowski, Z.; Magaj, J. Ship Domain as a Safety Criterion in a Precautionary Area of Traffic Separation Scheme. TransNav Int. J. Mar. Navig. Saf. Sea Transp. 2017, 11, 93-98. [CrossRef]

38. Pietrzykowski, Z.; Magaj, J. Ship Domains in Traffic Separation Schemes. Zeszyty Naukowe/Akademia Morska w Szczecinie 2016, 45, 143-149.

39. Xiang, Z.; Hu, Q.Y.; Shi, C.J.; Yang, C. Computation method of ship domain in restricted waters based on AIS data. J. Traffic Transp. Eng. 2015, 5, 110-117.

40. Xi, Z.; Jin, Y.; Hu, Q.; Xiang, Z. Ship domain in the restricted waters under restricted visibility. J. Shanghai Marit. Univ. 2016, 37, $18-21$.

41. Wielgosz, M. Ship Domain in Open Sea Areas and Restricted Waters: An Analysis of Influence of the Available Maneuvering Area. TransNav Int. J. Mar. Navig. Saf. Sea Transp. 2017, 11, 99-104. [CrossRef]

42. Gil, M.; Montewka, J.; Krata, P.; Hinz, T.; Hirdaris, S. Determination of the dynamic critical maneuvering area in an encounter between two vessels: Operation with negligible environmental disruption. Ocean Eng. 2020, 213, 107709. [CrossRef]

43. Montewka, J.; Gil, M.; Wróbel, K. Discussion on the article by Zhang \& Meng entitled "Probabilistic ship domain with applications to ship collision risk assessment". Ocean Eng. 2019, 186, 106130.

44. Goerlandt, F.; Pentti, K. Traffic simulation based ship collision probability modeling. Reliab. Eng. Syst. Saf. 2011, 96, 91-107. [CrossRef]

45. Weng, J.; Dong, Y. Investigation of shipping accident injury severity and mortality. Accid. Anal. Prev. 2015, 76, 92-101. [CrossRef]

46. Lu, Z.; Kang, L.; Gao, S.; Meng, Q. Determination of minimum distance to obstacle avoidance in the Singapore strait. Transp. Res. Rec. 2018, 2672, 73-80. [CrossRef]

47. Niksa, R.T.; Szłapczyński, R. A framework of a ship domain-based near-miss detection method using mamdani neuro-fuzzy classification. Pol. Marit. Res. 2018, 25, 14-21.

48. Peng, X.; Wen, Y.; Wu, L.; Xiao, C.; Zhou, C.; Han, D. A sampling method for calculating regional ship emission inventories. Trans. Res. Part D Transp. Environ. 2020, 89, 102617. [CrossRef] 